\title{
HROB DIEŤAŤA V NÁDOBE Z PLOCHY ZANIKNUTÉHO KOSTOLA A CINTORÍNA V PINCINEJ (OKRES LUČENEC)
}

\author{
ZUZANA POLÁKOVÁ - VÁCLAV FURMÁNEK - IVETA KACZAROVÁ
}

\begin{abstract}
Abstrakt: Počas výskumu zaniknutého stredovekého kostola v polohe Temetödomb v katastri obce Pinciná sa zistila rekonštruovatel’ná keramická nádoba. Vyzdvihnutá bola zo sondy III-A-2, ktorá križovala exteriér juhozápadného nárožia lode stavby a sčasti prechádzala aj cez jeho murivo. Pri revizii nálezového fondu sa ukázalo, že v nádobe boli pôvodne uložené kosti diet’at’a. Tento pozoruhodný nález sa radi k detským hrobom $v$ nádobách, ktorých výskyt na území Slovenska eviduje historická archeológia od 14. do 17. storočia. Etnografické pramene posúvajú praktizovanie tohto zvyku až do začiatku 20. storočia. Najbližši obdobný nález pochádza z lokality Gortva-Bizovo, kde bola nádoba s kosṫami novorodenca uložená v lodi zaniknutého kostola. Nález z Pincinej je d'alším príkladom využitia locus sacer et consecratus zaniknutého kostola a jeho cintorína na pohreb pravdepodobne nepokrsteného diet'at'a.
\end{abstract}

Kl'účové slová: Pinciná-zaniknutý kostol a cintorín-novovek-diet’a v nádobe-locus sacer et consecratus.

An Infant's Grave in a Vessel from the Area of a Defunct Church and Graveyard in Pinciná (Lučenec District)

Abstract: Research into a defunct medieval church in Temetödomb, in the cadastral zone of the Pinciná village, yielded a ceramic vessel which was possible to reconstruct. It was located in test pit III-A-2 that crossed the exterior of the south-western corner of the church nave and partially intersected its masonry. The revision of the finds showed that the vessel had originally contained the bones of an infant. This remarkable find ranks with infants' graves in vessels, the occurrence of which in Slovak territory is confirmed by historical archaeology from the 14th century until the 17th century. However, ethnographic sources shift the practising of this custom as late as the early 20th century. The closest similar find comes from Gortva-Bizovo where a vessel with the bones of an infant was interred in the nave of a defunct church. The find from Pinciná is another example of the use of the locus sacer et consecratus of a defunct church and its graveyard for the burial of possibly an unbaptized infant.

Key words: Pinciná - defunct church and graveyard - modern age - infant in a vessel - locus sacer et consecratus.

V predkladanom príspevku sa zameriavame na výnimočný a špecifický nález, ktorý sa získal v 80. rokoch minulého storočia. V rokoch 1981-1984 sa v polohe Temetődomb v Pincinej uskutočnil záchranno-systematický archeologický výskum, ktorý mal za ciel' preskúmat’ mohylovitý útvar, o ktorom sa predpokladalo, že pochádza z mladšej doby bronzovej (Budinský-Krička 1934). Počas štyroch výskumných sezón sa odkryl pôdorys neskororománskeho kostola a preskúmal sa kostolný cintorín (Furmánek-Tóthová 1982; 1982a; 1983; 1984; 1984a). Vzhl’adom na skutočnost', že lokalita nebola komplexne vyhodnotená, znovuobjavenie tohto nálezu prišlo až v súvislosti s podrobnejšou analýzou kostolného cintorína (Poláková 2015). Pri práci s materiálom v depozitári Novohradského múzea a galérie v Lučenci sa dohl'adali črepy z rekonštruovatel'nej keramickej nádoby s jej pôvodným obsahom. Tieto nálezy sú predmetom štúdie.

\section{Historické pozadie kostola a výskumu v Pincinej}

Obec Pinciná leží v Lučenskej kotline na nive rieky Ipel' v strednom Poiplí (obr. 1). V písomných prameňoch sa s ňou prvýkrát stretávame v donačnej listine z roku 1326 (,possessio Pynch... in comitatu Neugradiensi existens"; AO II/256). V roku 1329 sa spomína v súvislosti s obcou kňaz („Dom. Sac. Eccl-e de Pench“; Györffy 1998, 284). V zozname pápežských desiatkov z 30. rokov 14. storočia sa však kostol neobjavuje (porovnaj Sedlák 2008). O existencii fary sa dozvedáme až v roku 1542 v listine, kde sa farárovi predpisuje mimoriadna daň vo výške dvoch flor (Trochta 1971-1972, VIII, 32). V roku 1554 sa v kontrolnom registri Sečianskeho sandžaku spomína farár Gál vo výpočte obyvatel'stva Pincinej (Vass 1993, 41). V súčasnosti sa 


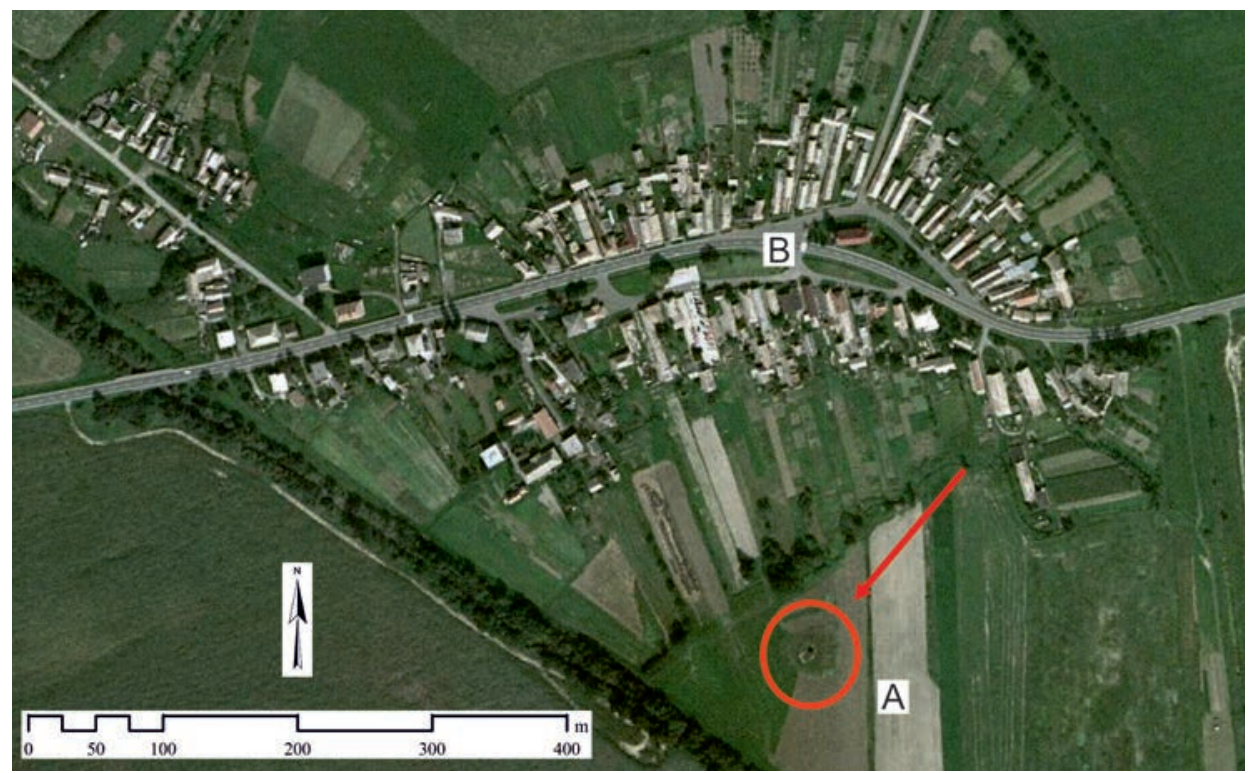

Obr. 1. Pinciná, okr. Lučenec. Ortofotografický pohl'ad na intravilán a čast' extravilánu. A - lokalizácia zaniknutého kostola v polohe Temetődomb; B - existujúci Kostol Všetkých svätých v strede obce. Mapový podklad Eurosens, s.r.o. a Geodis, s.r.o., upravila Z. Poláková.

Abb. 1. Pinciná, Bezirk Lučenec. Orthofotografische Ansicht des Innenbereichs und eines Teils des Außenbereichs der Gemeinde. A - Lokalisierung der untergegangenen Kirche in der Lage Temetődomb; B - existierende Allerheiligenkirche im Zentrum der Gemeinde. Kartenvorlage Eurosens, s.r.o. und Geodis, s.r.o., erstellt von Z. Poláková.

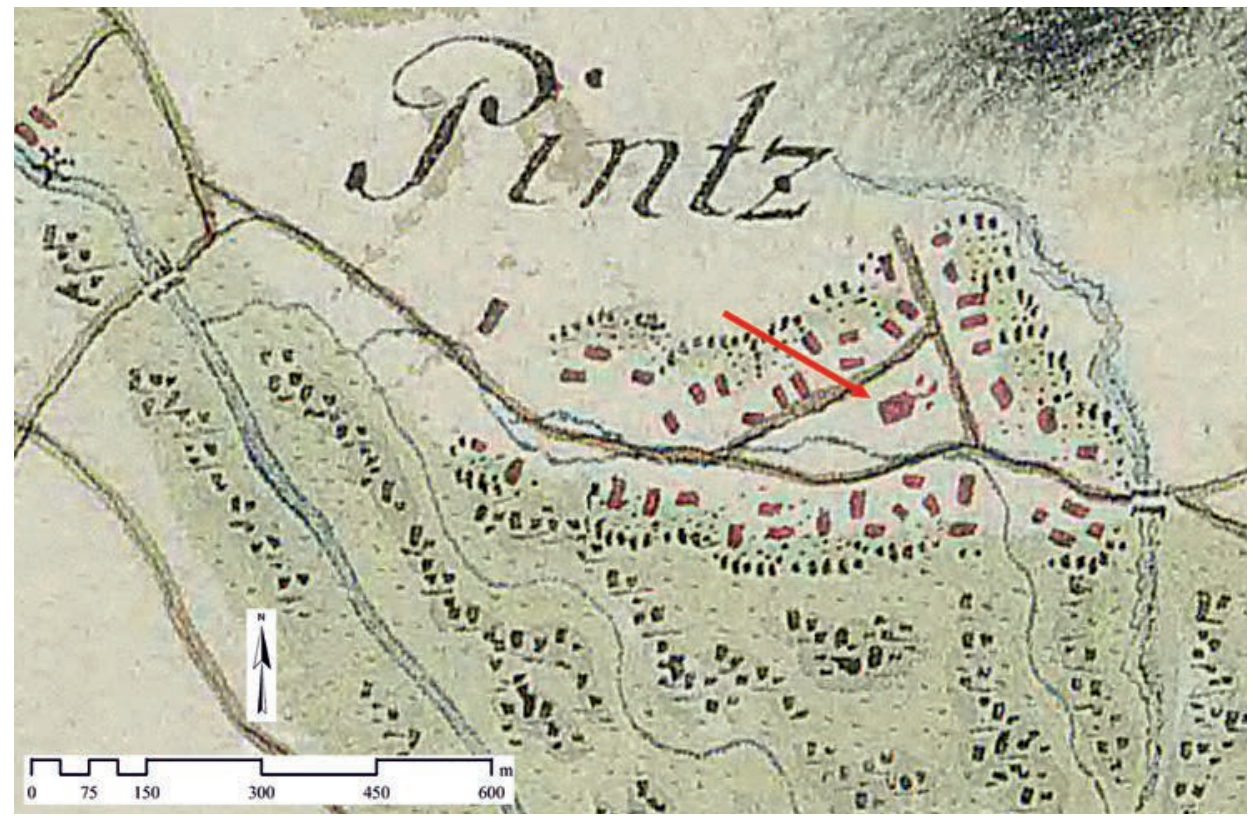

Obr. 2. Pinciná, okr. Lučenec. Prvé vojenské mapovanie (1769-1784). Kostol v intraviláne obce. Archeologicky skúmaný zaniknutý kostol južne od obce na mape nie je zaznačený. Mapový podklad www. geoportal.sazp.sk, upravila Z. Poláková. Abb. 2. Pinciná, Bezirk Lučenec. Erste militärische Kartierung (1769-1784). Die Kirche im Innenbereich der Gemeinde. Die archäologisch untersuchte, untergegangene Kirche südlich von der Karte ist auf der Karte nicht eingezeichnet. Kartenvorlage www. geoportal.sazp.sk, erstellt von Z. Poláková. 
v obci nachádza kostol s patrocíniom Všetkých svätých z roku 1901, ktorý bol postavený na starších základoch (obr. 1-2; Borovszky 1911, 103). Pôvodný kostol pravdepodobne podlahol niektorému z požiarov v 19. storočí. Doposial' sa nám nepodarilo získat' bližšie informácie o staršom kostole v obci, rovnako ako o zaniknutom neskororománskom kostole.

Preskúmaný zaniknutý kostol sa nachádza v polohe Temetődomb („Cintorínsky kopec“), južne od intravilánu obce, asi 250 m južne od cesty z Lučenca do Rimavskej Soboty (obr. 3). Poloha je situovaná približne $100 \mathrm{~m}$ od súčasného l’avého brehu Ipl'a, v jeho inundačnom pásme. Archeologicky je známa už od 30. rokov 20. storočia. V roku 1931 a 1934 vykonával V. Budinský-Krička v katastri obce archeologický prieskum i záchranný výskum pri rekonštrukcii cesty z Lučenca do Rimavskej Soboty (V. B. 1939, 11, 16). V tom čase si všimol aj mohylovitý útvar v zmienenej polohe (Budinský-Krička 1934). Polohu v nasledujúcich rokoch síce obhliadli aj iní, k výskumu však došlo až začiatkom 80 . rokov 20. storočia. Jeho pôvodne záchranný charakter (z dôvodu projektu rekultivácie a meliorácie pozemkov, ktorého dôsledkom malo byt' porušenie a zničenie lokality) sa postupne zmenil na systematický. Uskutočnil ho Archeologický ústav SAV v Nitre (V. Furmánek) v spolupráci s Novohradským múzeom v Lučenci (I. Kaczarová, za slobodna Tóthová), pričom v poslednom roku spoločného výskumu (1983) práce prešli pod Novohradské múzeum (Furmánek-Tóthová 1982; 1982a, 83-86; 1983, 87-88; 1984; 1984a, 80-81; Furmánek 1990, 369-373; Tóthová 1988).

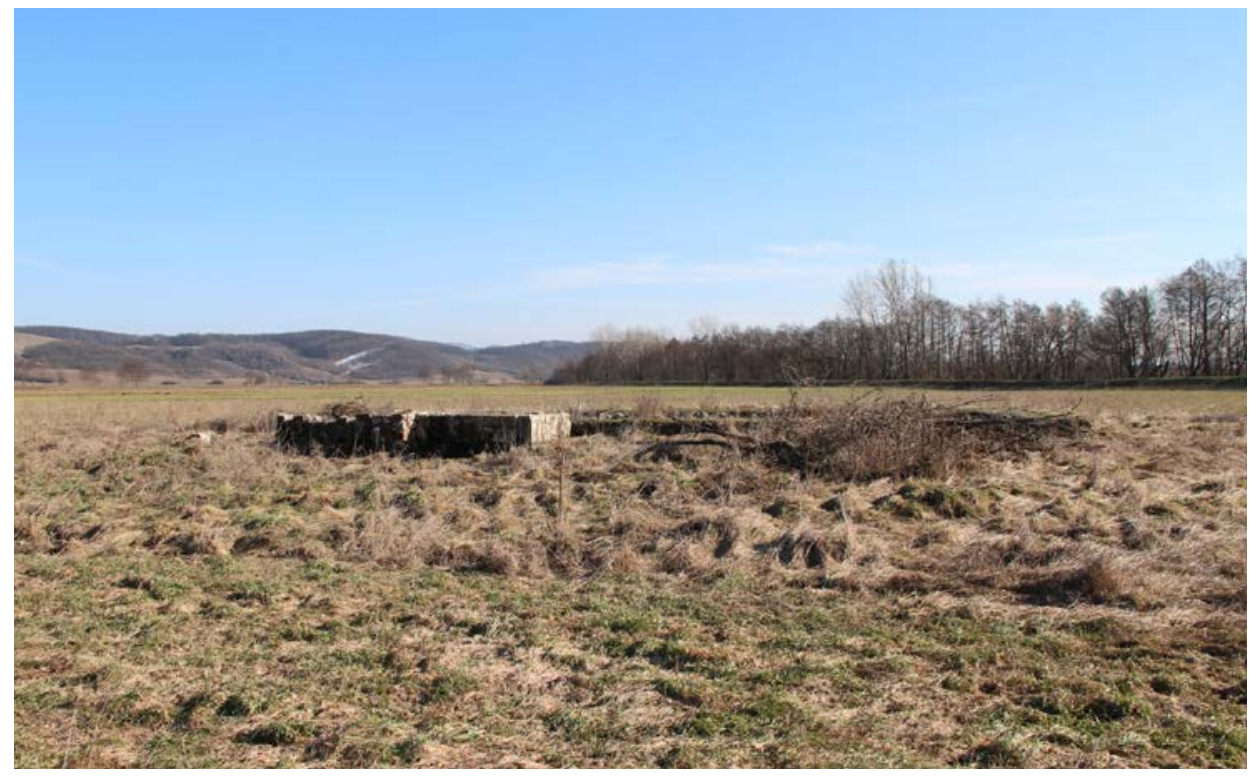

Obr. 3. Pinciná, okr. Lučenec. Poloha Temetődomb, súčasný stav. Pohl’ad zo severozápadu. Foto Z. Poláková, 2013. Abb. 3. Pinciná, Bezirk Lučenec. Lage Temetődomb, heutiger Zustand. Blick aus Nordwesten. Foto Z. Poláková, 2013.

\section{Kostolný cintorín v Pincinej}

Kostolný cintorín (obr. 4) je možné vd’aka hrobovému inventáru, ako aj charakteristickej neskororománskej tehlovej sakrálnej architektúre datovat' do obdobia od prelomu 12. a 13. až do 17. storočia. Jeho spodnú hranicu determinujú esovité záušnice v hroboch 29/81 a 202/84. Vrchná hranica je určená hrobovými nálezmi mincí a devocionálií. Na preskúmanej lokalite bolo zásluhou zistenej stratigrafie možné rámcovo vyčlenit' tri fázy pochovávania. Prvú fázu predstavuje pochovávanie pri stojacom funkčnom kostole a je totožné s dobou existencie sakrálnej stavby. Druhá fáza bola vyčlenená na základe predpokladu o zániku sakrálnej funkcie kostola a jeho postupnom zanikaní, pričom sa na lokalite nad’alej pochováva. Definitívny zánik stavby 
a malú rozlíšitel’nost' jej zvyškov na povrchu predstavuje pochovávanie v tretej fáze, ktoré sa uskutočňuje vd’aka tradícii existencie sakrálnej stavby. Signifikantné sú pre ňu hroby s výrazne odlišnou orientáciou $(\mathrm{Z}-\mathrm{V})$, obsah stavebnej sute v zásype hrobových jám, zapustenie hrobov do vrstiev s prítomnost'ou stavebnej sute, hroby porušujúce murivá stavby, ako aj ich uloženie na rozobratých murivách architektúry.

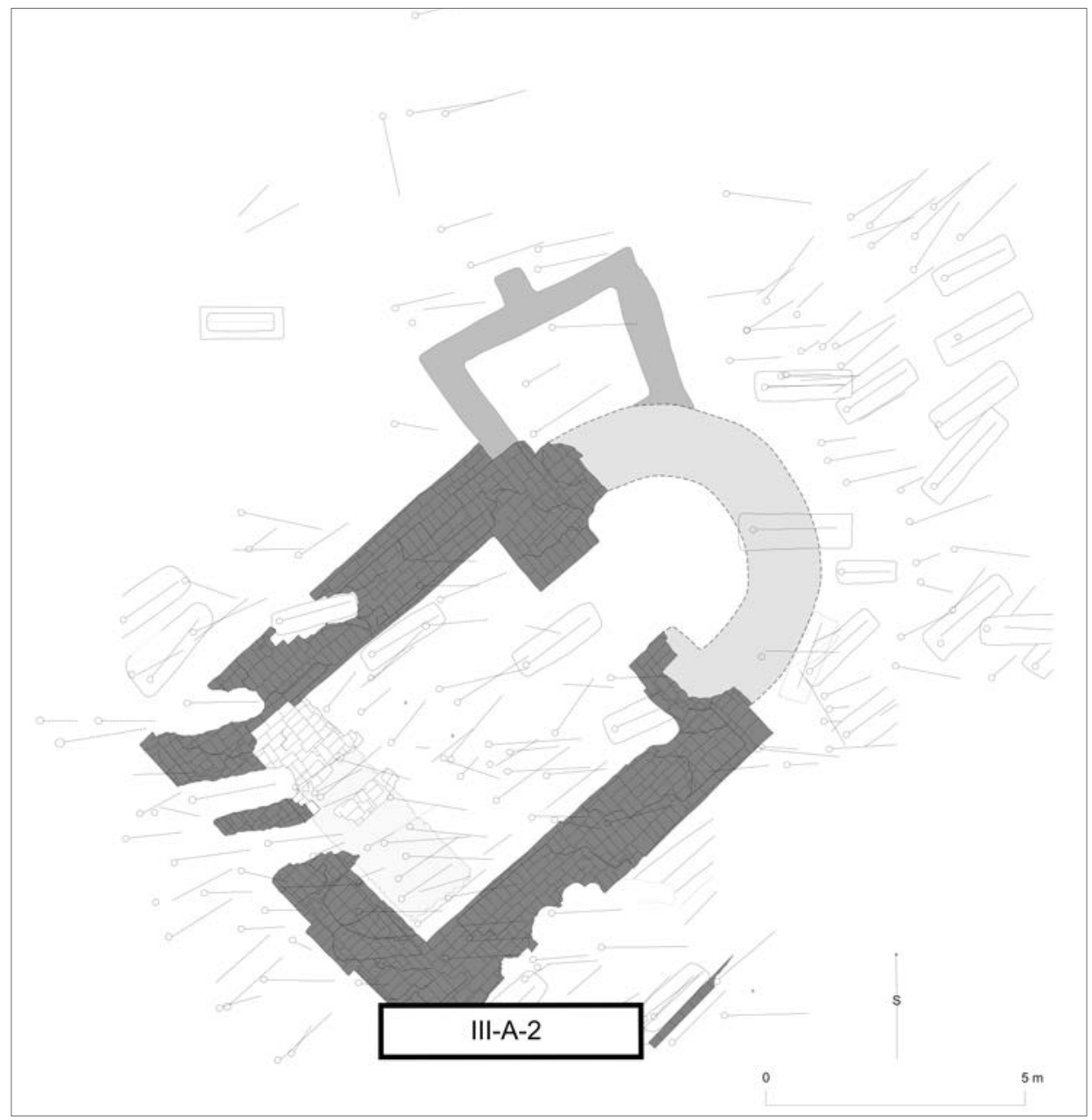

Obr. 4. Pinciná, poloha Temetődomb, okr. Lučenec. Preskúmaný zaniknutý kostol a cintorín s vyznačenou čast’ou sondy, v ktorej sa našla keramická nádoba. Podl’a Furmánek-Tóthová 1982, 1984; upravila Z. Poláková.

Abb. 4. Pinciná, Lage Temetődomb, Bezirk Lučenec. Untersuchte untergegangene Kirche und Friedhof mit eingezeichnetem Teil des Sondierschnitts, in dem das Keramikgefäß gefunden wurde. Nach Furmánek-Tóthová 1982, 1984; erstellt von Z. Poláková.

Druhú fázu pochovávania vyčleňujú hroby v interiéri kostola (obr. 5). Porušenost' pôvodnej tehlovej podlahy a vzájomné stratigrafické vzt’ahy svedčia o tom, že $\mathrm{k}$ pochovávaniu v tejto fáze mohlo dôjst' až po zániku funkčnosti sakrálnej stavby. Absencia hrobového inventáru si vynucuje uvažovat' skôr o širšom období, v ktorom dochádza k zániku sakrálnej funkcie kostola. Sú dve možnosti interpretácie. Kl'účovým pre datovanie je hrob 73/81, situovaný v juhozápadnom vnútornom rohu stavby. Na základe nálezu kostenej opaskovej garnitúry (Furmánek-Tóthová 1982a, 360 , obr. 57:1, 2, 3, 5) je možné hrob datovat' do 15 . storočia (s prihliadnutím na analógie z územia Slovenska, ako aj Mad’arska; bližšie pozri Poláková 2015, 262-264). O jeho pravdepodobnom 


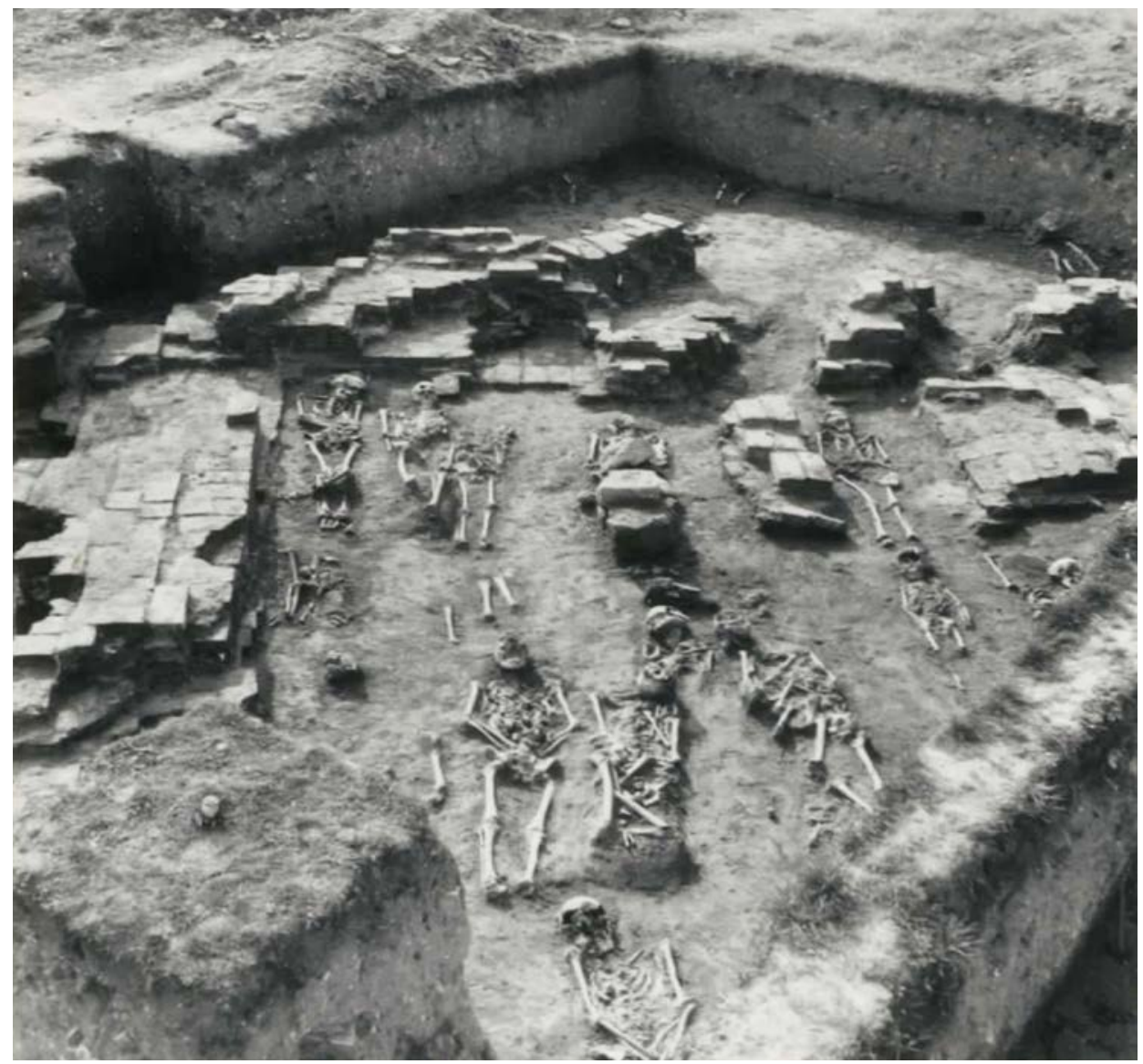

Obr. 5. Pinciná, poloha Temetődomb, okr. Lučenec. Pohl'ad na čast’ preskúmaných hrobov v interiéri zaniknutého kostola. Podl'a Furmánek-Tóthová 1982.

Abb. 5. Pinciná, Lage Temetődomb, Bezirk Lučenec. Blick auf einen Teil der untersuchten Gräber im Innern der untergegangenen Kirche. Nach Furmánek-Tóthová 1982.

zaradení do druhej fázy pochovávania svedčí jeho vel’mi tesné situovanie v nároží stavby, pričom podl’a kresbovej dokumentácie ležal sčasti aj na rozšírenom základovom murive lode, a tiež jeho príliš plytké zahĺbenie vzhl'adom na zachovanú niveletu tehlovej podlahy, ako aj na rozhranie základového a nadzákladového muriva kostola. V prípade správnej interpretácie a možnosti zániku kostola datovaného na základe tohto hrobu do 15. storočia je možné sa opriet' o historické udalosti. Zánik kostola by sme mohli spájat's významnou historickou udalost’ou, ktorá sa odohrala v roku 1451. Udalost’ známa ako „bitka pri Lučenci“ znamenala ničivú porážku vojsk uhorského gubernátora Jána Huňadyho husitskými vojskami vedenými Jánom Jiskrom z Brandýsa. Nevel'ká vzdialenost' Pincinej od Lučenca (cca $9 \mathrm{~km}$ ) mohla mat' neblahé následky aj na život v tejto obci. $\mathrm{Z}$ historických prameňov vieme, že $\mathrm{v}$ tomto období boli mnohé kostoly a hrady v regióne poškodené. Preto vidíme možnú príčinu zániku kostola práve v súvislosti s pôsobením bratríkov v tomto priestore v polovici 15 . storočia. Z d’alších hrobov, ktoré mohli prispiet' k datovaniu druhej fázy pochovávania, sú hroby 83/81 (Poláková 2015, II, tab. LXXII:83:1, 2; d’alej uvádzame už iba čísla tabuliek) a 86/81 (tab. LXXII:86:2) v interiéri kostola, ktoré obsahovali mince. Určená mohla byt' len minca z hrobu 86/81, ide o razbu Ferdinanda I. (1526-1564; tab. LXXII:86:1; FurmánekTóthová 1982). Minca pochádza zo zásypu hrobovej jamy. Jediným dokladom priameho stratigrafického vzt’ahu medzi staršími hrobmi v interiéri a samotným kostolom je hrob 87/81, ktorý 
porušuje stavbu z interiéru a hrob 90/81, ktorý svojím uložením porušil tehlovú podlahu. Všetky tieto hroby dodržujú orientáciu kostola. Ďalšia minca zo 16. storočia sa už našla v exteriéri v hrobe 128/82, ktorý takisto leží zhodne s dlhšou osou kostola (tab. LXXXXVII:128:1). Jediný hrob, ktorý obsahuje mincu a zároveň je v superpozícii so stavbou, je hrob 37/81 (tab. LIX:37:1, 2). V hrobe sa našli dve mince datované do 17. storočia. Domnievame sa, že medzi obdobím zanikania stavby a jej definitívnym zánikom musel uplynút istý časový úsek, čo podmienilo aj výrazne odlišnú orientáciu hrobov jedincov pochovaných v tretej fáze, kedy už kostol nemohol byt’ na povrchu takmer rozlíšitel'ný a uchováva sa len tradícia pochovávania v tomto priestore (locus sacer et consecratus; obr. 6). Z toho dôvodu vidíme obdobie 16. storočia ako najneskoršie pre datovanie zániku stavby. Svedčia o tom aj hroby 186/82 a 208/84 s najstaršími mincami zo 17. storočia s razbami Mateja II. (1608-1619), prípadne hrob 195/83 s razbou Gabriela Bethlena z roku 1621, ktoré sa vyznačujú už zmenenou Z-V orientáciou. V prípade, že by interpretácia hrobu 73/81 v lodi kostola bola nesprávna, zánik kostola môžeme spájat' s turbulentnými udalost’ami a tureckým nebezpečenstvom v polovici 16. storočia. Z tohto dôvodu kladieme druhú fázu pochovávania na kostolnom cintoríne v Pincinej rámcovo do 15.(?)-16. storočia.

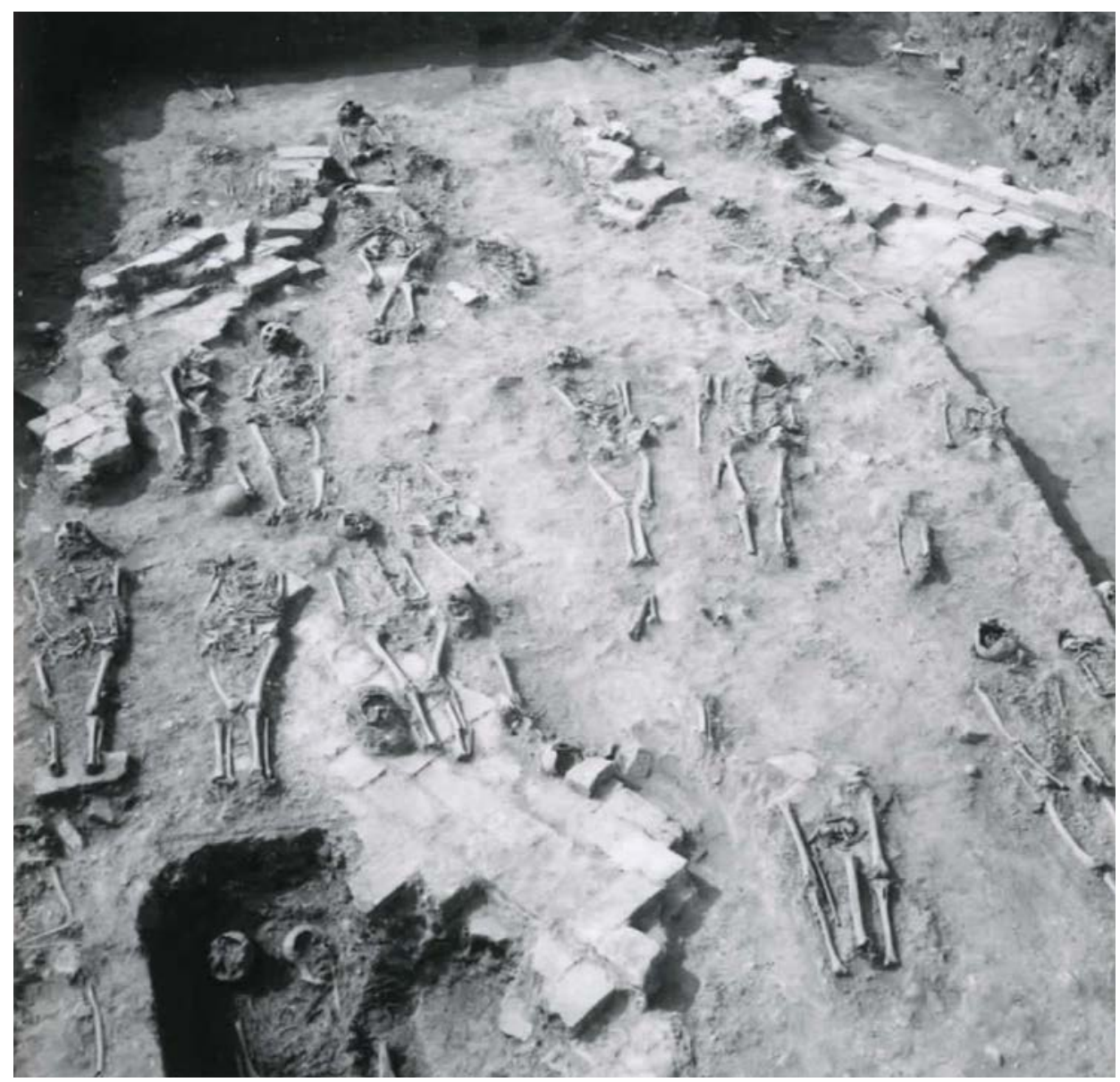

Obr. 6. Pinciná, poloha Temetődomb, okr. Lučenec. Pohl’ad na hroby tretej fázy pochovávania na lokalite. Podl’a Furmánek-Tóthová 1982.

Abb. 6. Pinciná, Lage Temetődomb, Bezirk Lučenec. Blick auf die Gräber der dritten Bestattungsphase an der Fundstelle. Nach Furmánek-Tóthová 1982. 
Kontinuita pochovávania na mieste zaniknutých kostolov a ich cintorínov nie je ojedinelý fenomén a podrobnejší pohlad na nálezové situácie z mnohých zaniknutých kostolov naznačuje, že s týmto javom treba počítat'. K zanikaniu kostolov dochádzalo vel’akrát v dôsledku nečakaných udalostí, na ktoré miestni obyvatelia nemuseli byt' pripravení. Preto môžeme predpokladat', že za takýchto okolností alebo v čase vedomej výstavby nového kostola na inom mieste, ako aj v rámci dlhodobej tradície, mohol priestor samotného zaniknutého kostola a jeho areálu nad’alej slúžit' k pochovávaniu. Okrem regulárneho pochovávania sa môžeme na takýchto miestach stretnút' aj s hrobmi l'udí, ktorým nebolo umožnené spočinút' na existujúcom kostolnom cintoríne (napr. nepokrstené deti). V takomto prípade mohlo íst' o ojedinelé hroby alebo menšiu skupinu hrobov.

Tradícia pochovávania nebožtíkov do trosiek starších cirkevných stavieb je v stredoeurópskom priestore doložená už na prelome 11. a 12. storočia (kostol 6 v Mikulčiciach; Slivka 1997, 75). Najznámejším príkladom kontinuity pochovávania z územia Slovenska aj napriek zániku sakrálnej stavby je Ducové, poloha Kostolec. Štvrtá fáza pochovávania na tejto lokalite (druhá polovica 10. až polovica 15. storočia) je charakteristická tradíciou existencie sakrálnej stavby. Je zaujímavé, že uloženie hrobov začína severne od kostola, to znamená, že hroby sa bezprostredne nekoncentrujú okolo samotnej stavby. Postupne však vyplínajú plochu cintorína okolo kostola (Ruttkay 1996, 394). V 13. storočí sú už niektoré z hrobov zahíbené do zrútených blokov muriva južných stien rotundy (Ruttkay 1984, 13). Funkciu cintorína si priestor udržal do 19. storočia.

Pochovávanie aj po zániku kostola bolo dokumentované tiež na iných lokalitách Slovenska, či už na ploche kostolného cintorína (napr. Hurbanovo-Bohatá, poloha Páldomb - Habovštiak 1961, 472, 473, 475) alebo priamo do sutín kostola (napr. Levice, poloha Baratka - Habovštiak 1963, 432; Nemešany, poloha Koscilek - Polla 1962, 38; Radol'a, poloha Koscelisko - Petrovský-Šichman 1963, 241-242, 246-248, 252-253, 256).

\section{Hrob diet'at’a v nádobe z Pincinej}

Analýza kostolného cintorína s celkovým počtom 228 preskúmaných hrobov zaznamenala takmer výlučné (223 hrobov; 98 \%) pochovávanie mŕtvych v charakteristickej vystretej polohe na chrbte. Táto skutočnost' nepriniesla nič prekvapujúce. V štyroch hroboch bolo uloženie neurčitel'né. Iba v jednom prípade sa podarilo zachytit' uloženie mŕtveho na bruchu. Hrob 130/82 ležal v exteriéri kostola, severovýchodne od apsidy (Furmánek-Tóthová 1984; Poláková 2015, II, tab. LXXXVIII:130). Vo väčšine prípadov boli mŕtvi uložení v hrobe samostatne. Ojedinele sa však stretávame aj s existenciou dvojhrobov - detských jedincov v mužských hroboch (5/81, 81/81; Furmánek-Tóthová 1982, 5; Poláková 2015, I, 84, 206-209). Jediným prekvapením bol hrob diet’at’a v nádobe, ktorý sa v rámci terénneho výskumu neidentifikoval. V druhej sezóne výskumu, v roku 1982, sa podarilo získat' rekonštruovatel'nú keramickú nádobu. Črepy boli vyzdvihnuté z novootvorenej sondy III-A-2, ktorá bola situovaná v exteriéri juhozápadného nárožia lode kostola a sčasti prechádzala aj cez jeho rozobraté murivo (obr. 4). Pri revízii nálezového fondu sa ukázalo, že v nádobe boli pôvodne detské kosti. Tieto boli uložené v papierovom vrecku spolu s črepmi a s poznámkou ,kosti z nádoby“. Vd’aka uvedeným poznatkom sme mohli vyvodit' záver, že v prípade nálezu rekonštruovatel'ných črepov išlo o pôvodný hrob diet’at'a v nádobe. Spôsob uloženia kostry v nádobe už nebolo možné určit'. Nálezové okolnosti (predovšetkým vel'mi plytké uloženie - hĺbka 0,30 m) umožňujú predpokladat', že k uloženiu diet’at’a v nádobe mohlo dôjst' až v tretej fáze pochovávania, čiže v dobe, kedy už kostol nebol na povrchu takmer viditel'ný, ale stále sa tu udržiavala tradícia pochovávania.

Nádoba, ktorá obsahovala kosti (v. $220 \mathrm{~mm}$, ø ústia $150 \mathrm{~mm}$, 凤 dna $100 \mathrm{~mm}$ ), je hrncovitého tvaru s bočným pásikovým uchom z okruhu bielej mal’ovanej keramiky (obr. 7, 8). Hrniec má vajcovitú profiláciu. Ústie je lievikovite von roztvorené. Nádoba bola vytáčaná na rýchlo rotujúcom kruhu. Telo hrnca je bohato zdobené červenohnedým mal'ovaným dekórom v podobe obežných pásov a vlnoviek, ako aj rytými obežnými ryhami do mal'ovaného ornamentu. Mal'ovaný je tiež okraj, ako aj ucho nádoby. Nad dnom je jeden širší obežný mal'ovaný pás. 


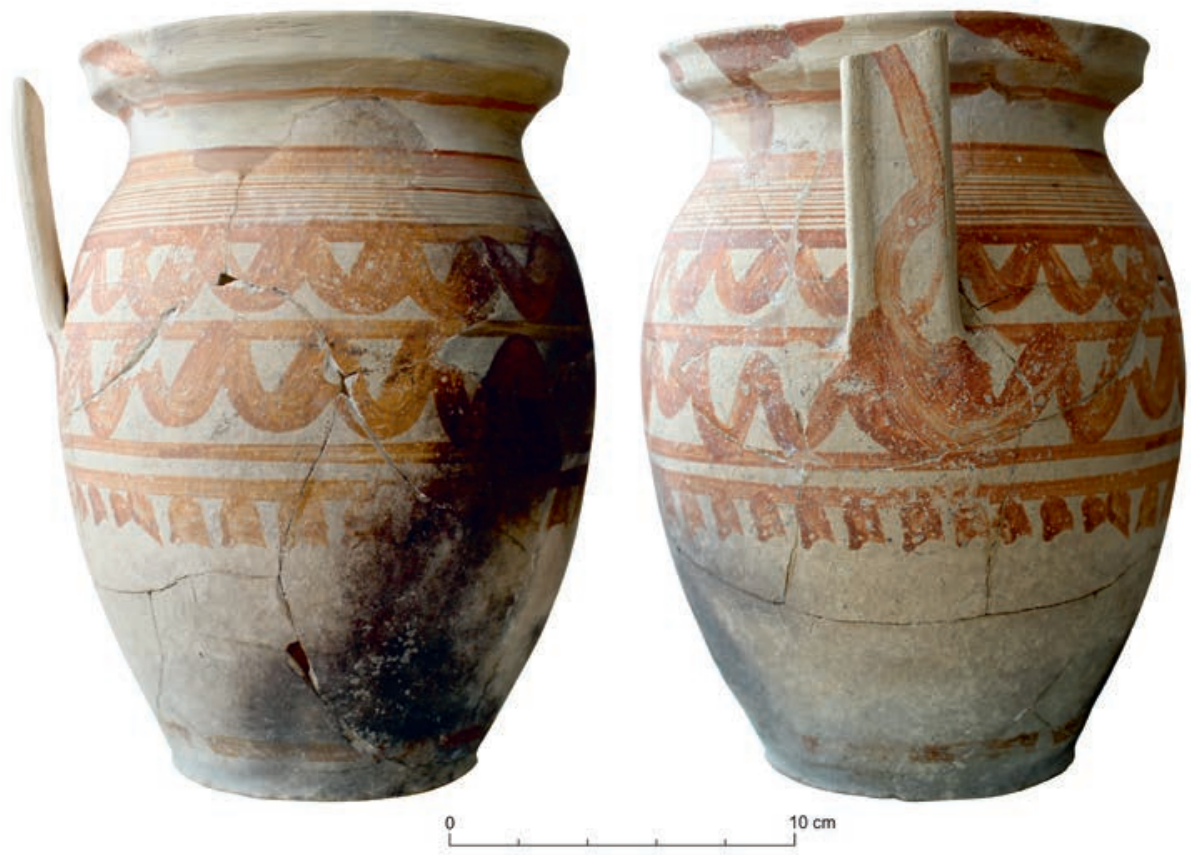

Obr. 7. Pinciná, poloha Temetődomb, okr. Lučenec. Keramická nádoba, ktorá obsahovala pozostatky detského jedinca. Foto Z. Poláková, 2013.

Abb. 7. Pinciná, Lage Temetődomb, Bezirk Lučenec. Keramikgefäß, das die Gebeine des Kindindividuums enthielt. Foto Z. Poláková, 2013.

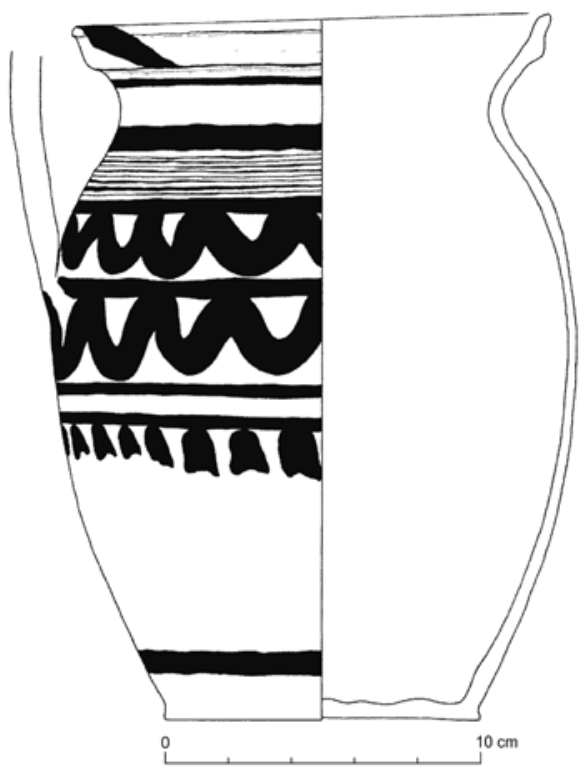

Obr. 8. Pinciná, poloha Temetődomb, okr. Lučenec. Keramická nádoba, ktorá obsahovala pozostatky detského jedinca. Kresba Ž. Nagyová.

Abb. 8. Pinciná, Lage Temetődomb, Bezirk Lučenec. Keramikgefäß, das die Gebeine des Kindindividuums enthielt. Zeichnung Ž. Nagyová.
Poznanie včasnonovovekej keramiky z územia južných regiónov stredného Slovenska je nedostatočné. Vzhl'adom na nepublikované nálezové celky a len postupne narastajúci záujem o novovekú keramiku sa pri datovaní nádoby z Pincinej môžeme zväčša opriet' o všeobecné charakteristiky keramiky z konca stredoveku a začiatku novoveku z Gemera, Malohontu a Novohradu. Na prelome 15. a 16. storočia sa na keramike začína výrazne uplatňovat' dekór z pásikov a vlnoviek (Hoššo 1985, 247). S uchom, ktoré bolo v staršom vývoji bielej keramiky charakteristické pre džbány, sa na hrncoch stretávame iba sporadicky v mladšom období stredovekej keramiky v týchto regiónoch (Hoššo 1985, 239). Doposial' sa nám nepodarilo v literatúre nájst' presnú analógiu k nálezu z Pincinej, ktorá by kombinovala všetky jej tri signifikantné vlastnosti (tektoniku tela, okraj nádoby, výzdobu). Poznáme však viacero podobných prevedení. Vel'mi blízku paralelu nachádzame medzi nálezmi z hradu Hollóko $\mathrm{v}$ mad’arskej časti Novohradu. Malovaný hrniec datovaný do 
17. storočia (Kozák 1975, 49, obr. 29) je charakteristický obežnými líniami na hrdle a výduti, striedajúcimi sa s obežnými líniami vlnoviek na jeho tele. Ucho hrnca je vytiahnuté nad okraj. Podobný charakter má aj mal’ovaný hrniec z archeologického výskumu na ulici B. Bartóka v Rimavskej Sobote (Botoš 2013, 24, obr. 13). Hrniec je zdobený mal’ovanými pásmi a vlnovkami červenohnedej farby, ako aj rytými obežnými ryhami. A. Botoš $(2013,24,25)$ datuje nádobu z objektu 6/2010 do druhej polovice 16 . až začiatku 17. storočia, pričom na základe výsledku dendrochronologickej analýzy sa prikláňa skôr k obdobiu polovice 16. storočia. Z Rimavskej Soboty pochádza d’alší súbor keramiky, ktorý má blízke paralely s nálezom z Pincinej. Celé nádoby, ako aj torzá nádob, ktoré sa našli v studni počas výstavby prevádzkovej budovy Sociálnej poistovne na ulici I. Mikszátha, sú datované od druhej polovice 16. až do 18. storočia. Charakteristická je pre ne mal’ovaná výzdoba, ktorá pokrýva značnú čast' nádoby. Vzdialenejšie paralely k okraju nachádzame medzi okrajmi typu A (Botoš 2012, 236, tab. 1). Tektonikou tela je blízky hrniec s nevýrazným lievikovite von roztvoreným a duto profilovaným ústím (Botoš 2012, 241, tab. 4:3). S charakterovo podobnou keramikou sa stretávame aj medzi nálezmi z hradu Eger v 17.-18. storočí (Fodor-Kozák 1972, predovšetkým 164, obr. 6, l’avý spodný). Keramika je bohato mal'ovaná. V tomto prípade sú však hrnce zvnútra glazúrované.

Nádoba z Pincinej nemá zachované napojenie ucha k okraju, môžeme však predpokladat' vysoko vytiahnuté ucho, bud' zarovno s okrajom, alebo vytiahnuté nad okraj hrnca, ktoré sa objavuje v tomto období (Fodor-Kozák 1972, 160, obr. 2, 161, obr. 3, 164, obr. 6, 179, obr. 24; Kozák 1975, 49, obr. 29).

Keramickú nádobu je možné podl'a tvaru, profilovania okraja a predovšetkým bohatej mal'ovanej výzdoby rámcovo zaradit' do 16. (možno skôr jeho druhej polovice) a 17. storočia (porovnaj Botoš 2012; 2013; Hoššo 1985; Kozák 1975; za konzultáciu d’akujeme Alexandrovi Botošovi).

Kostrové pozostatky diet’at'a sa zachovali vo vel'mi dobrom stave (obr. 9). Antropologickú analýzu realizovali antropologičky Michaela Dörnhöferová a Silvia Bodoriková z Katedry antropológie Prírodovedeckej fakulty Univerzity Komenského v Bratislave. Touto cestou im vel'mi pekne d’akujeme. Antropologická analýza bude publikovaná na inom mieste, a preto zostáva len konštatovat', že vzhl'adom na odhadnutý vek jedinca môžeme uvažovat' o predčasnom pôrode (bližšie Poláková 2015, 85, 206).

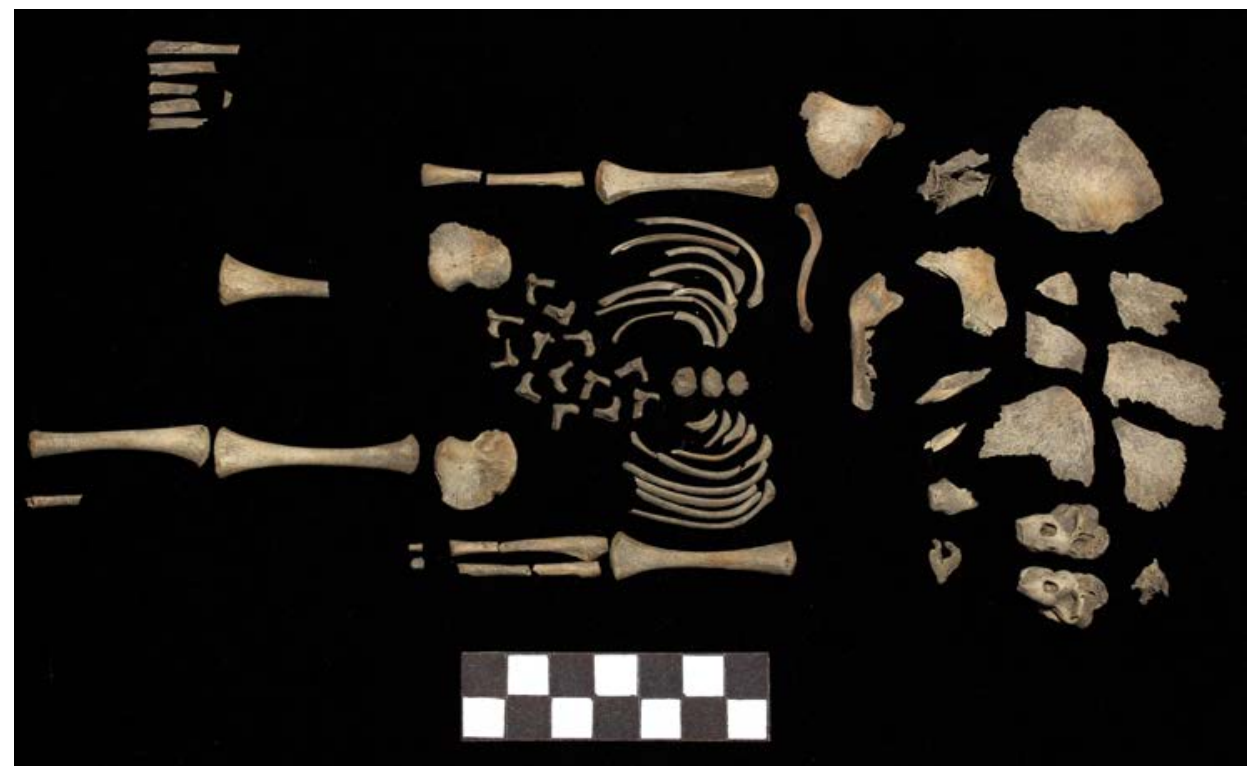

Obr. 9. Pinciná, poloha Temetődomb, okr. Lučenec. Pozostatky detského jedinca. Foto Z. Poláková, 2013. Abb. 9. Pinciná, Lage Temetődomb, Bezirk Lučenec. Gebeine des Kindindividuums. Foto Z. Poláková, 2013. 


\section{Hrob diet’at'a v nádobe - pohl'ad archeológie v stredoeurópskom priestore}

Problematike detí v nádobách sa už venovala pozornost', v Pol’sku dokonca v monografických výstupoch (Duma 2010, 31-57; 2015, 95-108). Známe sú obšírnejšie štúdie týchto pol'ských bádatel'ov: B. Zawadzka-Antosik (1973), E. Kowalczyk (2004), L. Miechowicz (2007). Na Slovensku je doteraz jediným príspevkom k tejto téme inšpiratívna štúdia M. Slivku (1997). Problematika sa d’alej skúmala len pri vyhodnocovaní jednotlivých lokalít, a to predovšetkým Krásna (Krupica 1978, 185-187; Gogová 2013, 23-27), ale aj d’alších nálezov (pozri nižšie). V Čechách a na Morave sa táto tematika dostala skôr do prác venovaných bud’ širšej otázke pochovávania (Unger 2006, 124-133; Králiková 2007, 111-112), alebo stat' bola zaradená v štúdii o pochovávaní novorodencov (Čechura 2011, 291-292). Z Mad’arska je nám nateraz známa viac-menej len štúdia M. Béres (1995, 31-33), z Nemecka spracovania nálezov z jednotlivých lokalít (Heintel 1961; Freist 1975) a pod.

\section{Hroby detí v nádobách na území Slovenska v stredoveku a novoveku}

Z regiónov juhu stredného Slovenska poznáme okrem diskutovaného hrobu z Pincinej ešte jeden nález. Ten je už v odbornej literatúre známy dlhšie a pochádza z Gortvy-Bizova, polohy Bukové (región Gemer). Nádoba s novorodencom (obr. 10; našli sa kosti rúk a nôh, antropologicky určil M. Thurzo; Drenko 1994, 132, 147, 150, pozn. 2) bola uložená v lodi zaniknutého kostola. Hrniec (v. $330 \mathrm{~mm}$; ø ústia $185 \mathrm{~mm}$, 凤 dna $125 \mathrm{~mm}$ ) patrí tiež do okruhu bielej keramiky, mal vyšší štíhly tvar s červeným mal'ovaným vodorovným dekórom pod hrdlom (Drenko 1994, 132, 141, obr. 14:2). Hrniec je možné rámcovo datovat' do 16. storočia (porovnaj napr. Hoššo 1985, 237, obr. 4:1, 256-258; Slivka 1997, 79, obr. 3:3). Vzhl’adom na nálezové okolnosti mohlo k uloženiu nádoby dôjst' až po zániku kostola, teda niekedy na začiatku 17. storočia (porovnaj Slivka 1997, 75). Aj v tomto prípade bolo využité locus sacer $\mathrm{k}$ pochovaniu pravdepodobne nepokrsteného diet’at’a. Oba nálezy je možné zaradit' $\mathrm{k}$ d'alším známym detským hrobom v nádobách zo stredovekých a novovekých nálezísk na Slovensku. Doposial' bolo v odbornej literatúre evidovaných sedem lokalít (porovnaj Slivka 1997). Historická archeológia ich výskyt na sledovanom území zaznamenáva od 14. do 17. storočia na troch, resp. štyroch základných priestorových vymedzeniach v súvislosti so sakrálnou stavbou (podl’a archeologických výskumov):

- mimo vysvätenej pôdy - za kostolnou ohradou (extra muros),

- v priestore kostolného cintorína, ale na špecifickom mieste,

- v priestore zaniknutého kostola a jeho kostolného cintorína:

- v sutinách kostola,

- pochovávanie sa uskutočňuje v rámci kontinuity či tradícií pochovávania.

Nádoba s hrobom diet’at'a mohla byt' uložená za kostolnou ohradou, teda mimo vysvätenej pôdy. Na Slovensku sa takéto hroby našli v polohe Chríb v Krásne (Krupica 1954, 364-365; 1978, 185-188) a v polohe Kuzma v Hurbanove-Bohatej (Habovštiak 1961, 462-463, 472, obr. 13). V Hurbanove-Bohatej je doposial' archeologicky zaznamenaný najstarší doklad (14. storočie; Slivka 1997, 74) tohto spôsobu pochovania diet'at’a na území Slovenska v zmysle stredovekého a novovekého pochovávania. Nález detskej kostry v hrnci, ktorý bol situovaný tesne za priekopou - teda mimo samotného cintorína, predchádzal výskumu lokality (Habovštiak 1961, 462, 472).

Z Krásna pochádza až sedem hrobov s pozostatkami detských jedincov lokalizovaných za murovanou kostolnou ohradou, z nich takmer všetky boli umiestnené za jej jednotlivými opornými piliermi. Ten posledný ležal o niečo d’alej za ohradou. Hroby boli charakteristické pomerne plytkým uložením $(0,20-0,40 \mathrm{~m})$, polohou na boku s ústím orientovaným smerom ku kostolu a vo väčšine z nich sa našli aj mince. Práve tie dobre datujú pohreby detí v nádobách od 15. storočia, minca Ladislava V. (1453-1457) v hrobe 8, až do 17. storočia, minca Ferdinanda II. (1619-1637) - kremnický denár z roku 1631 v hrobe 6 (Krupica 1978, 185-188). 

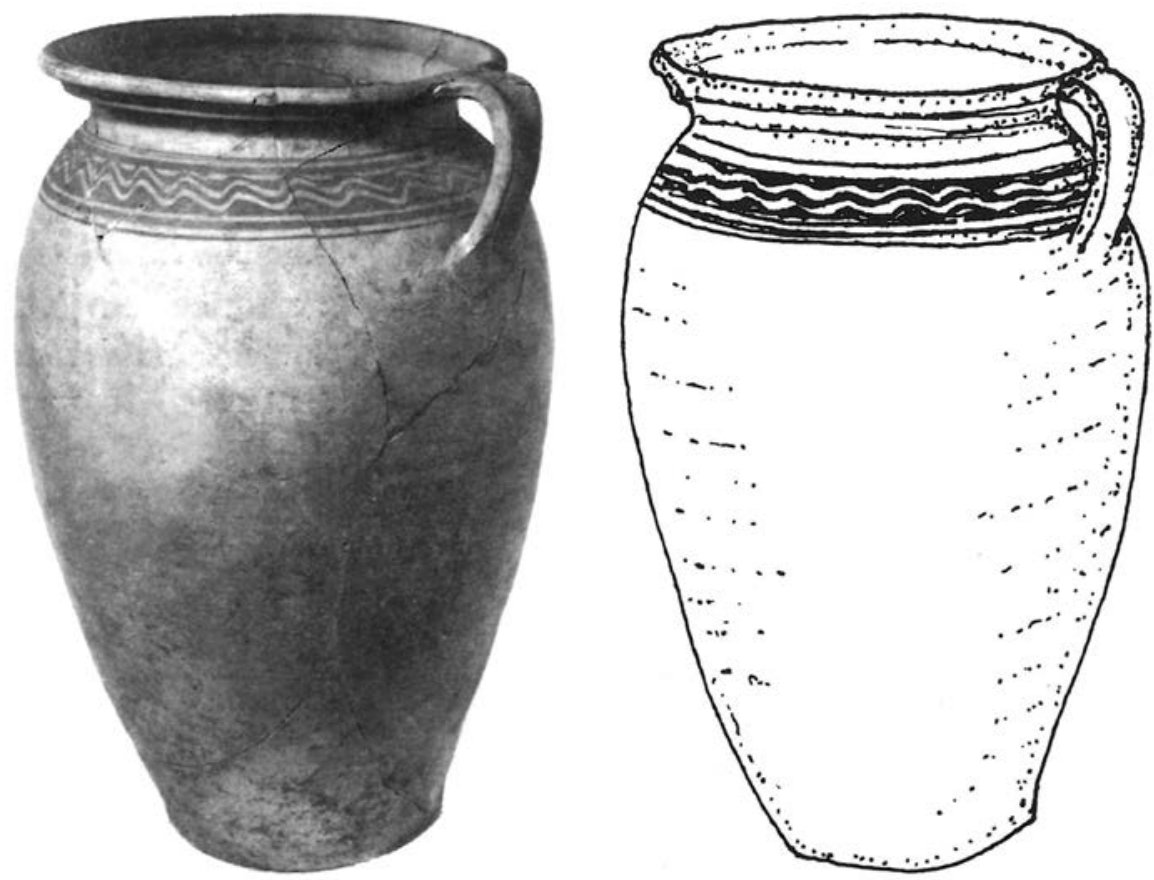

Obr. 10. Gortva-Bizovo, poloha Bukové. Keramická nádoba obsahujúca kosti novorodenca, bez mierky. Podl’a Drenko 1994, 141, obr. 14:2; Slivka 1997, 79, obr. 3:3, upravila Z. Poláková.

Abb. 10. Gortva-Bizovo, Lage Bukové. Keramikgefäß mit Säuglingsgebeinen, ohne Maßstab. Nach Drenko 1994, 141, Abb. 14:2; Slivka 1997, 79, Abb. 3:3, erstellt von Z. Poláková.

Na rozdiel od zmienených hrobov mohlo byt' diet’a $\mathrm{v}$ nádobe uložené takisto $\mathrm{v}$ priestore kostolného cintorína. Príkladom je opät' Krásno, kde bola nádoba situovaná pri východnej stene kostnice I, t. j. v priestore medzi ňou a ohradovým múrom cintorína. Hrob 3 bol nájdený v híbke 0,40 m a okrem detských kostičiek obsahoval aj uhorskú mincu Maximiliána II. (1564-1576) kremnický denár z roku 1566 (Krupica 1978, 186). Ďalší hrob sa našiel pri severozápadnom nároží kaplnky Božieho Tela, ktorá bola odkrytá pri Kostole sv. Štefana v Žiline-Závodí (Moravčík 1996, 1). Hrniec s pozostatkami novorodenca, v pôvodnom uložení s ústím orientovaným smerom na juh, je datovaný do rozhrania 16.-17. storočia (Moravčík 1996, 1). Existencia spomenutej kaplnky sa predpokladá v období od konca 14., resp. začiatku 15. až po polovicu 16. storočia, pričom v tomto období jej funkciu preberá novopostavený objekt nachádzajúci sa južne od Kostola sv. Štefana (Moravčík 1996, 3; 2011, nestr.).

Posledná skupina z územia Slovenska súvisí so zaniknutými kostolmi. Hroby mohli byt' situované do sutín kostola, čoho dokladom je zmienený nález z Gortvy-Bizova, ako aj d'alšie dve známe náleziská - Slovenská L’upča a Radol’a. V Slovenskej Lupči bola nádoba uložená v stavebnej sutine kláštorného Kostola sv. Ducha, v tesnej blízkosti oltárnej menzy. Hrob bol datovaný do druhej polovice 16. storočia (Hanuliak 2001, 7), kedy sa predpokladá, že areál kláštora, a predovšetkým jeho kostoly boli už nefunkčné (Hanuliak-Ragač 2000, 242, obr. 9). Do sekundárne vylámaného výklenku ambónu bola uložená nádoba s diet’at’om v polohe Koscelisko v Radoli. K uloženiu nádoby (rámcovo datovanej do 14.-15. storočia) došlo po zániku kostola, ktorý je stanovený najneskôr okolo roku 1450. Autor výskumu predpokladá vloženie detského hrobu do ambónu najneskoršie o 20-30 rokov neskôr (Petrovský-Šichman 1963, 241-242, 252-254, 256). Na druhej strane mohla byt' nádoba s hrobom diet’ata uložená na mieste zaniknutého kostola a cintorína (teda nemusí íst' jednoznačne o pochovanie priamo do sutín v interiéri kostola), s pretrvávajúcou tradíciou pochovávania. Príkladom je nález z Pincinej a hroby detí v polohe 
Kostolec v Ducovom. V Ducovom sa hrob diet'at'a v nádobe vyskytol už v 15. storočí, charakteristickejší je však pre obdobie 16. a 17. storočia. Dokumentovaný bol v štyroch prípadoch (Ruttkay 1984, 19, 22; 1992, 99).

Len pomerne nedávno sa $\mathrm{v}$ literatúre objavila zmienka o náleze pravdepodobného hrobu diet’at’a v nádobe z Kočína-Lančára. Z ryhy situovanej ned’aleko veže Kostola sv. Michala Archanjela $\mathrm{v}$ časti Lančár sa získala hrncovitá nádoba vyrobená na rýchlo rotujúcom hrnčiarskom kruhu (Klčo-Krupa 2004, 179, obr. 5). Vzhl'adom na skutočnost', že pri náhodnom náleze neboli prítomní archeológovia a nálezcovia nevenovali pozornost' jej obsahu, význam získanej nádoby bez kostrových pozostatkov je t’ažko bližšie vyhodnotit'.

Ďalší analogický nález bol pravdepodobne zaznamenaný v polohe Staré háje v katastri obce Solčany na strednom Ponitrí, ako uvádza O. Krupica $(1978,185)$ v súvislosti s nálezmi z Krásna.

\section{Hroby detí v nádobách z priestoru strednej Európy v stredoveku a novoveku}

Hroby detí v nádobách poznáme zo širšieho stredoeurópskeho priestoru. Popri slovenských lokalitách je ich najviac známych z Pol'ska. Z deviatich pol'ských lokalít (Duma 2015, 105-107, tab. 5) je väčšina $z$ nich situovaná v odlišnom prostredí ako v prípade slovenských nálezov. Hroby detí v nádobách boli umiestnené na chronologicky starších archeologických lokalitách. V štyroch prípadoch išlo o praveké a protohistorické pohrebiská - Brudnice (Miechowicz 2007, 56), Brzeźno (Zawadzka-Antosik 1973, 368), Grzybów (Duma 2015, 106) a Ożumiech (Zawadzka-Antosik 1973, 365-366). Zaujímavost’ou je hrob 2 z priestoru lužického pohrebiska v katastri Ożumiech. V nádobe zo 14.-15. storočia sa nachádzali kosti dvoch jedincov - 5 a 7 mesačného plodu (Zawadzka-Antosik 1973, 365). Z mladších lokalít spomenieme pohrebisko z doby rímskej - Brzeźno. Našiel sa tu hrob novorodenca z druhej polovice 19. storočia (Zawadzka-Antosik 1973, 368). Ďalšie tri lokality predstavovali včasnostredoveké náleziská. V dvoch prípadoch išlo o pohrebiská - Pieścidła (Zawadzka-Antosik 1973, 368) a Żukowo (Zawadzka-Antosik 1973, 368; Dzik 2006, 63-66); a v jednom prípade o hradisko - Serock (Zawadzka-Antosik 1968; 1973, 366-367). V Serocku bol plod pochovaný v nádobe obrátenej hore dnom, situovaný ned’aleko d’alších ôsmich hrobov v susedstve stratigraficky mladšej novovekej kaplnky, ktorá bola vystavaná pravdepodobne až začiatkom 17. storočia. Nádoba pochádza pravdepodobne z prelomu 15. a 16. storočia (Zawadzka-Antosik 1968, 365-366; 1973, 367). V Żukowe sa na včasnostredovekom pohrebisku našli najmenej 3 hroby detí v nádobách. V hroboch 23 a 29 sa našli najpravdepodobnejšie kosti plodov (Dzik 2006, 63).

Jedinou pol'skou lokalitou $\mathrm{s}$ doloženým prepojením hrobov detí v nádobách na cirkevnú stavbu sú Wyszatyce. V okolí prícestnej Kaplnky sv. Jána Nepomuckého sa našli početné nádoby $\mathrm{s}$ detskými ostatkami, situované v híbke $0,50-0,80 \mathrm{~m}$. Niektoré z hrobov boli prikryté keramickými náčiniami a iné z hrobov boli umiestnené hore dnom (Zawadzka-Antosik 1973, 368; Miechowicz 2007).

Najnovší nález z Pol'ska pochádza z výskumu v roku 2011 na námestí Nowy Targ v meste Wrocław. Ide o prvý nález tohto typu v pol’skom Sliezsku. Hrob diet'at’a sa však od známych príkladov odlišuje tak datovaním pohrebu, ako aj kontextom nálezu. Nádoba s pozostatkami diet’at’a bola vkopaná do sutín spáleného hrazdeného domu (rozmery 4,1 ×3,8 m) s otvorom hore a následne dôkladne prikrytá prepáleným výmazom pochádzajúcim z výplne zničených stien. Diet’a bolo vo veku ,okolo pôrodu“ - vel'mi neskorý plod (8-9 mesiacov) alebo novorodenec. Nádoba pochádza z 13. storočia, konkrétnejšie z jeho prvej polovice. Je otázne, či osoba, ktorá sem nádobu uložila, bola zviazaná s týmto domom. P. Duma (2015, 104-105) uvažuje, že samotné miesto naznačuje zámernú vol'bu.

Podobne datovaný kostolný cintorín ako v Pincinej poznáme z Mad’arska. Kostolný cintorín v Óföldeák bol preskúmaný v rokoch 1989-1999 s počtom 419 hrobov. Podla nálezov sa na ňom pochovávalo od 12. do 17. storočia. Zaujímavost'ou bol hrob 355, diet'a uložené v hrnci s hlavou hore, datovaný do 18. storočia. Nádoba bola situovaná za ohradovým múrom kostola a takisto aj za priekopou stredovekého kostola, ale stále $\mathrm{v}$ priestore cintorína, na ktorom sa 
v tomto rozsahu pochovávalo od prelomu 14. a 15. storočia. V nádobe, ktorá bola čiastočne uložená na boku a jej ústie smerovalo na juh, bol uložený plne vyvinutý plod, išlo o mŕtvo narodené diet’a alebo náhle zomrelého novorodenca (Béres 1995, 31, 32; 2005, 298, obr. 1; 302, obr. 7; 303).

Z Nemecka poznáme len spracovania jednotlivých nálezov (napr. Heintel 1961; Freist 1975). Väčšina z týchto lokalít je situovaná za múrmi kostolných cintorínov a datovaná do stredoveku (porovnaj Duma 2015, 105, tab. 5).

\section{Svet nepokrstených detí}

V odbornej literatúre sa hroby detí v nádobách interpretujú ako hroby nepokrstených detí. Takáto interpretácia nachádza svoje korene tak v historických a etnografických prameňoch, ako aj v archeologických a antropologických analýzach nálezov hrobov. V snahe o pochopenie príčin osobitého prístupu v zaobchádzaní s telami nepokrstených mŕtvych musíme načriet' do prv zmienených prameňov.

Podla krest’anskej náuky po tehotenstve, ktoré začína počatím a uzatvára sa pôrodom, prichádza krst diet’at’a (obr. 11, 12,13). Krst predstavuje očistu novorodenca od prvotného (dedičného) hriechu a je udelením Božej milosti, teda základnej podmienky prijatia do spoločenstva cirkvi (Navrátilová 2004, 74). Pre pochovanie pokrstených, t. j. krest’anov a zároveň tých, čo

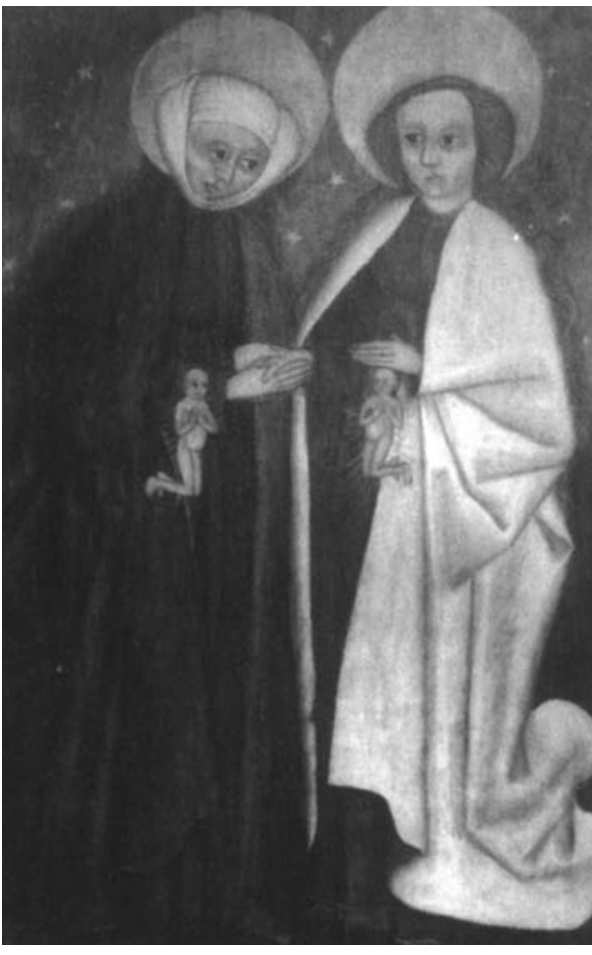

Obr. 11. Predstava samodruhej ženy. Tabul'ová mal'ba Navštívenia, posledná tretina 15 . storočia, pôvodne v drevenom rím.-kat. Kostole sv. Alžbety v Oravskej Porube-Zábreži (dnes v Oravskej galérii, Dolný Kubín). Podl'a Kovačevičová 2006, 38.

Abb. 11. Darstellung einer schwangeren Frau. Tafelbild Heimsuchung, letztes Drittel 15. Jahrhunderts, ursprünglich in der röm.-kath. Holzkirche St. Elisabeth in Oravská Poruba-Zábrež (heute in der Galerie Orava, Dolný Kubín). Nach Kovačevičová 2006, 38.

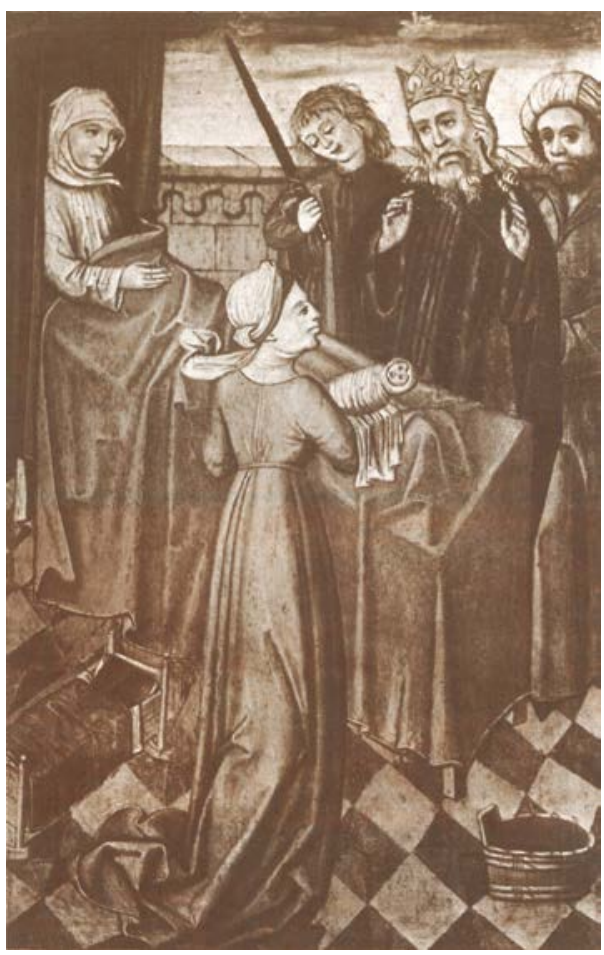

Obr. 12. Postel' šestonediel'ky. Tabul'ová mal'ba Narodenie sv. Alžbety, okolo roku 1480. Bardejov, rím.-kat. farský Kostol sv. Jakuba, oltár sv. Alžbety. Podl'a Kovačevičová 1987, 88, obr. 109.

Abb. 12. Wöchnerinnenbett. Tafelbild Geburt der Hl. Elisabeth, um 1480. Bardejov, röm.-kath. Pfarrkirche St. Jakob, Elisabethenaltar. Nach Kovačevičová 1987, 88, Abb. 109. 


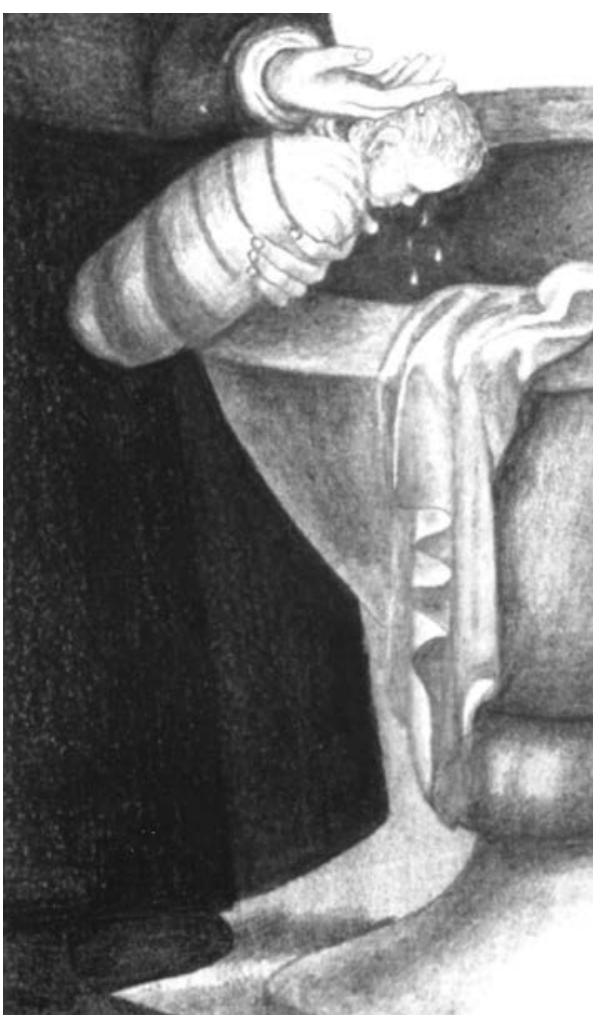

Obr. 13. Scéna krstu diet'at'a, detail oltára, okolo 1580. Gryfino, rím.-kat. Kostol Narodenia P. M., predtým Kostol sv. Mikuláša, autor Dawid Redtel. Podl’a Drążkowska 2007, 137, obr. 3.

Abb. 13. Szene einer Kindestaufe, Altardetail, um 1580. Gryfino, röm.-kath. Mariä-Geburt-Kirche, davor St. Nikolauskirche, Künstler Dawid Redtel. Nach Drążkowska 2007, 137, Abb. 3. žili v zhode s krest’anským učením, slúžil vysvätený priestor. Nepokrsteným det’om, zločincom či t’ažkým hriešnikom a samovrahom bolo však spočinutie vo vysvätenej pôde odopreté (Ariés 2000, 62-65; Kyll 1972, 120-121, 126; Ohler 2001, 175-176; Slivka 1997, 73; Unger 2006, 138). Cintorín (z gr. koiméterion od slova koimasthai - spat') ako vysvätený priestor značí posvätný „dormitár“ zosnulých a podla Honoria Augustodunského je lonom cirkvi (ecclesiae gremium), v ktorom cirkev kriesi duše, ktorých telo zomrelo a vracia ich večnému životu, podobne ako krstom privádza na svet mŕtvych (Ariés 2000, 62).

$\mathrm{V}$ gréckych a latinských textoch $\mathrm{v}$,,predaugustínovskom“ období nenachádzame žiaden dôkaz takej viery, podl'a ktorej by už samotný prvotný hriech v sebe zahrňoval trest po smrti, akým je aj vylúčenie z visio beatifica (blažené videnie Boha; Toner 1910, 256). To znamená, že nebol dôvod, prečo by nepokrstené deti mali byt' vylúčené z nároku na vzkriesenie a mali znášat' trápenia na onom svete. Vplyvom Augustínovej teológie však tieto deti prepadli večnému zatrateniu (Slivka 1997, 74). Sv. Augustín odmietol existenciu medzipriestoru alebo akéhokol'vek priestoru, kde by nepokrstené deti žili v štastí (Toner 1910, 257). V 12. storočí sa bipolárny charakter onoho sveta (peklo a nebesá) rozrastá o tretiu eschatologickú oblast' - purgatorium (očistec), t. j. miesto, ktoré dáva nádej na budúcnost' (Dinzelbacher 2004, 20-21). Neskôr ešte priberá aj d'alšie dve časti - limbus patrum (limbus patriarchov Starého zákona) a limbus puerorum (limbus nepokrstených detí). Limbus (z latinčiny - „okraj“, „hranica“ alebo „lem“) znamená okraj pekla, menej hrozné vedlajšie peklo, predpeklie (Dinzelbacher 2004, 85). Limbus patriarchov bolo pôvodným miestom pobytu spravodlivých pred vtelením Krista a zavedením krstu, ktorý Ježiš Kristus vyprázdnil, ked’ zostúpil do pekiel, aby vyviedol jeho obyvatel'ov do nebies (Le Goff 2008, 462). Limbus infantium alebo puerorum bolo trvalé miesto alebo stav nepokrstených detí a iných, ktorí zomreli bez závažnej osobnej viny a z dôvodu samotného prvotného/dedičného hriechu nikdy neuvidia Božiu tvár (Toner 1910, 256). Bolo to teda zvláštne miesto odpočinku bez trestu (Le Goff 2008, 462). Tento systém ,piatich“ miest prebývania duše (receptacula) v podsvetí sa dotvoril v 13. storočí - infernus (peklo), limbus puerorum, limbus patrum, purgatorium (očistec), paradisus (pozemský raj). Sporná náuka o limboch však nebola nikdy vyhlásená za článok viery (Rulíšek 2006, heslo limbus).

Obrad krstu sa spočiatku vykonával len príležitostne. Synoda v Mainzi v roku 813 určila vykonávanie krstu dvakrát do roka, na Vel'kú noc a na Turíce, čo pravdaže platilo aj pre novonarodené deti. Od 12. storočia to bolo postupne upravované v znení neskorších predpisov a v 13.-14. storočí sa od tejto praxe upustilo. Vzhl'adom na vysokú detskú úmrtnost', obzvlášt' $\mathrm{v}$ tom najmladšom veku v období stredoveku a novoveku, a strachu z toho, že diet'a zomrie bez krstu, bolo možné v núdzových prípadoch, aby farár vykonal krst kedykol’vek alebo existovala tiež možnost' núdzového krstu (nem. Nottaufe) akýmkol’vek dospelým (Illi 1992, 58; 
Kyll 1972, 120). Ak žena zomrela počas alebo pred narodením diet’ata, katolícka cirkev preferovala cisársky rez na vyslobodenie diet’at’a a jeho urýchlený krst. Poslednou šancou bolo pokropenie placenty alebo pupočnej šnúry svätenou vodou. V novoveku existovali osobitné nástroje na špeciálny krst ,in utero“. Napriek tomu, že snahou bolo vykonat' krst čo najskôr po narodení diet’at’a, stretávame sa aj so situáciami, ktoré, naopak, nevyhnutný krst odd’alovali. To sa odohrávalo hlavne v aristokratických kruhoch a súviselo to s prípravou vel'kolepejších osláv (bližšie Čechura 2011, 293, 294; tam aj d’alšia literatúra).

Ako bolo už uvedené, nepokrstené deti boli vyňaté z pohrebu vo vysvätenom priestore. Prvýkrát sa stretávame s nariadením o vydelení miesta na cintoríne pre nepokrstené a malé deti vo veku, pred ktorým začali používat' rozum, v Rímskom rituáli (Rituale romanum) z roku 1614 (citované podla Kowalczyk 2004, 104). Nepokrstené deti boli teda pochovávané mimo kostolného cintorína, resp. mimo vysvätenej pôdy. Z prameňov však vieme, že ich telá mohli spočinút' aj vo vymedzenom posvätenom či neposvätenom priestore v rámci cintorína. Pravdepodobným dôkazom toho sú aj početné archeologické nálezy plodov či novorodencov v areáli kostolných cintorínov. Nesúlad medzi kanonickým právom a archeologickými nálezmi svedčí o všeobecných t’ažkostiach pri vysporadúvaní sa so smrtou detí (Illi 1992, 57).

Skutočnost', že ohrada kostola a jeho cintorína bola akousi pomyselnou hranicou (porovnaj Slivka 2004, 16) a vymedzovala sacrum od profanum, dokumentuje viacero archeologických situácí́. Na jednej strane stoja hroby detí v keramických nádobách pochovaných v okolí kostolnej ohrady, extra muros (Hurbanovo-Bohatá, Krásno), čomu predchádzala motivácia blízkych dostat' ich do bezprostredného susedstva so sacrum. Na druhej strane, hraničný charakter ohrady a zároveň ambivalentný status nepokrstených detí vcelku výstižne charakterizujú hroby vo výklenkoch ohradových múrov kostolov, ktoré poznáme zo zahraničia (napr. Bláha 1996, 179; Illi 1992, 57). O d’alších miestach, ktoré už boli mimo kostolného vysväteného areálu, sa dozvedáme vel'akrát len z historických, ako aj etnografických prameňov, ked’že tieto sa málokedy stávajú predmetom archeologického výskumu a ak áno, tak ide o náhodné okolnosti. Takéto miesto, Burchardom z Wormsu označované ako locus secretus a v meste Trier roku 1310 opísané ako extra cimiterium (Kyll 1972, 121), sa mohlo nachádzat' na určitej lokalite v lese, poli, na rázcestiach ciest, pri hraničných kameňoch, krížoch, prícestných sochách svätých a prícestných kaplnkách v rámci alebo za hranicami dediny (Duma 2010, 19-20; Kowalczyk 2004, 104; Miechowicz 2007, 535).

Špecifické potom bolo pochovávanie v rámci vysvätenej pôdy, locus consecratus. Tu sa stretávame tiež s niekol'kými možnost’ami. V areáli kostolného cintorína mohli byt' vyčlenené osobité miesta pre pohreby nepokrstených detí, aby sa dosiahlo ich izolovanie od zvyšku zosnulých. Tento priestor mohol byt' dokonca plánovaný už pri zakladaní kostolného areálu a zostal nevysvätený. Takýmto spôsobom sa dodržalo kanonické právo a zároveň sa dosiahla kontrola nad pohrebmi nepokrstených detí, čím sa vyhovelo neutíchajúcemu úsiliu rodičov zabezpečit' pre svoje diet’a dôstojné miesto (porovnaj Kyll 1972, 122). Jedným z miest slúžiacim týmto potrebám bola oblast' situovaná popri vnútornej strane ohrady, ktorá síce bola vo vysvätenom priestore, ale v istom zmysle bola hodnotená ako okrajová. Preto sa v archeologickom bádaní môžeme ojedinele stretnút' aj s hrobmi l'udí, ktorí boli vnímaní okrajovo, v tesnom kontakte vnútornej strany kostolnej ohrady (napr. Hurbanovo-Bohatá, hrob 24 - Habovštiak 1961, 471; Slivka 1997, 74). Okraj cintorína, kde sa pochovávali nepokrstené deti, sa v Hornom Falcku označoval ako unschuldigen Kinder-Friedhof, ako antipendant k miestu, kde sa pochovávali deti pokrstené - v Šumavskom podhorí v Čechách nazývané ako Engelgarten (Ploss 1876, 84). Z archeologických prameňov poznáme napr. nálezovú situáciu z námestia Münsterhof v Zürichu, kde boli novorodenci a dojčatá pochovávaní na liturgicky nevýznamnom severozápadnom okraji cintorína, v tesnom susedstve s ohradou (Illi 1992, 57).

Ďalší špecifický priestor v rámci locus consecratus bol vyhradený v tesnej blízkosti kostola, pretože sa verilo, že voda v podobe dažd’a padajúca na strechu budovy prichádza v d’alšej postupnosti na zem už ako svätená. Takto malo byt' diet’a očist'ované či pokrstené až po smrti a dodatočne chránené pred zlými silami vd’aka blízkosti svätyni. Z toho je odvodené aj označe- 
nie „odkvapové deti“, v nem. Traufkinder (Ohler 2001, 175-176; Slivka 1997, 73-74). V tomto duchu mohli byt' deti umiestňované aj pri vnútornej strane ohradového múru, ak mal striešku. Na Šumave v Čechách je pochovávanie nepokrstených detí pod odkvapom doložené ešte koncom 19. storočia (Navrátilová 2004, 245).

Ďalším priestorom mohlo byt' miesto „za kostnicou“, v okrajovej časti v rámci ohradeného priestoru. Kostnice sa v l'udových predstavách vnímali ako príbytky chudobných duší (Duma 2010, 23; Illi 1992, 57, 61; Kyll 1972, 119; Slivka 1997, 74).

Absencia trvalého miesta duší nepokrstených detí na onom svete vzbudzovala strach u širokých más l'udí. V l'udovej viere sa teda obavy spájali s dušami nenarodených (potratených), mŕtvonarodených a nepokrstených (nepomenovaných) detí (Navrátilová 2004, 246). Tieto deti zostávali „na polceste“ (Štajnochr 2001, 335) v ich putovaní. Bohatá etnografická literatúra ponúka vel'a príkladov rôznych povier a protirevenantských praktík, ktorými sa malo predchádzat' v ich návrate do pozemského života (bližšie napr. Duma 2010, 18-26; Kowalczyk 2004, 107-108; Miechowicz 2007, 530-532). Zároveň sa v závislosti na mieste pochovania a druhu smrti od nich odvodzoval aj celý rad duchov a démonických foriem (Miechowicz 2007, 531).

Treba ešte podotknút', že etnologické štúdie prinášajú vel’a poznatkov o tom, že pohrebu potratených, mŕtvonarodených a nepokrstených detí sa v minulosti nevenovala zvýšená pozornost'. Ešte z 50. rokov 20. storočia pochádza údaj, že takéto deti zabalili len do plienky alebo do kusa papiera a vložili do škatule od margarínu (Navrátilová 2004, 247). Navonok „necitlivý““ postoj voči smrti diet’ata $\mathrm{z}$ dôvodu ich vysokej úmrtnosti neznamenal emocionálny nezáujem. Do istej miery bol určite spôsobený aj vysokými nákladmi spojenými s pohrebom, rovnako bežnou praxou takýchto „rýchlych“ procesov. Tragédiu smrti však určite každá rodina prežívala v intimite vlastného vnútra.

\section{Nádoba ako „hlinená rakva“ nepokrstených detí v stredoveku a novoveku}

Je prirodzeným naturelom človeka, že sa snaží vypátrat' dôvody, ktoré motivovali našich predkov pre vykonanie určitého skutku. V prípade javu, ktorý je predmetom tejto štúdie, sa však objavuje podozrenie, že aj napriek historickým a etnografickým prameňom, ktoré sú schopné zasadit' tento archeologický nález do kontextu, nebude nikdy možné naplno rozvinút' príbeh jednotlivého pohrebu v danom prostredí a v čase. Videli sme, že rozšírenie tohto zvyku minimálne v rozmedzí strednej Európy, je značné. Hroby detí v nádobách poznáme z Pol'ska, Slovenska, Nemecka a Mad’arska. Na tomto mieste možno pripomenút', že pochovávanie detí v nádobách nie je len neskorostredoveký a novoveký jav. S tzv. „pithosmi“, ako sa takéto hroby nazývajú, sa na Slovensku stretávame už v pokročilejšom štádiu staršej doby bronzovej, v prostredí sídlisk mad’arovskej a severopanónskej kultúry. Priepast' niekol'kých storočí nám nedovol'uje tieto javy uvádzat' do súvislostí, hoci nemožno vylúčit, že v istých základných predstavách mohli mat' podobné črty. Je možné len konštatovat', že „určité kultúrne prejavy sa objavujú, miznú a opät’ sa dostávajú do povedomia l'udu, hoci i v rozdielnom priestore a čase“ (Mitáš 2004, 5).

Prečo však v neskorom stredoveku a novoveku zaznamenávame opätovne tento jav v priestore strednej Európy a čo motivovalo matku alebo blízkeho príbuzného, aby diet’a na mieste jeho posledného uloženia spočinulo práve $\mathrm{v}$ nádobe?

Nádoby slúžiace v rôznych obdobiach dejinného vývoja na uloženie ostatkov mítvych sa niektorými autormi pokladajú za jeden z možných archetypálnych návratov do lona (regressus ad uterum) matky, čo vyplýva z mystického myslenia, podl’a ktorého je duša mŕtveho zárodkom nového bytia (Štajnochr 2001, 335). Podl'a M. Slivku $(1997,76)$ matka inštinktívne vkladá svoje mŕtve diet’a do „temnej dutiny“ nádoby, akou je aj materské lono (uterus), aby duša mohla dôstojne prebývat'. Dieta sa takýmto uložením vracia do embryonálnej polohy, čiže takej, akú malo pred smrtou v lone matky (Duma 2010, 32; Slivka 1997, 76). Aj nádoby, ktoré sa pre tieto účely používali, zodpovedajú vel'kost'ou nedokonale vyvinutému l'udskému plodu (Krupica 1978, 188).

Na rozdiel od „symbolického významu“ bola nádoba v praktickom ponímaní pravdepodobne náhradou rakvy - „hlinená rakva“ (Ruttkay 1992, 99; Zawadzka-Antosik 1973, 369). 
Vo všeobecnosti použitie rakvy v pohrebnom ríte vychádzalo zo snahy o zamedzenie kontaktu tela s okolitou zemou (Jágerová 2008, 177-178). Uloženie diet’at’a do nádoby mohlo byt' popri inom tiež motivované prirodzenou snahou o zabránenie kontaktu detského telíčka so zemou, aby sa telo zachovalo „čisté“. Podl’a R. Bednárika $(1972,30)$ v l’udovej viere nádoba symbolizovala čistotu. Skutočnost', že tieto „hlinené rakvy“ dokonale ochránili drobné detské pozostatky, konštatovala už B. Zawadzka-Antosik $(1973,369)$ na základe zachovanosti skeletov publikovaných v jej štúdii. Podl'a bádatel'ky (Zawadzka-Antosik 1973, 370) nádoba predstavujúca rakvu môže byt' prejavom vel'kej materskej starostlivosti o zachovanie detského tela. Vyplýva to $\mathrm{z}$ toho, že aj napriek pominutel'nosti smrtel'ného tela v protiklade s nesmrtel'nou dušou bolo potrebné poskytnút' telu patričné miesto posledného odpočinku a postarat' sa o jeho dôstojné zachovanie. Zároveň mohlo íst' o súhrn predstáv, ktoré vychádzali z prirodzenej túžby matky alebo blízkeho príbuzného o zabezpečenie ochrany malého tela, teda to posledné, čo sa mohlo diet'at'u dat'.

Niektorí bádatelia však použitiu nádoby v pohrebnom kontexte nepripisujú až taký vel'ký význam, ale rozmýšlajú skôr o praktických dôvodoch. R. Bednárik $(1972,30)$ uvažuje, či na tento druh pochovávania nemohlo mat' vplyv vel'ké množstvo vyrobených hrncov (konkrétne pre región Novohrad) a ich dobrá dostupnost'. Podobný názor má E. Kowalczyk $(2004,108)$, ktorá zdôrazňuje, že boli elementárnym kontajnerom v každej domácnosti. V tomto smere je zaujímavé, že aj nádoba z Pincinej nesie stopy pôvodného používania v domácnosti. O varení na otvorenom ohni svedčí časté zadymenie strany oproti uchu hrnca (Hoššo 2004, 570), ktoré pozorujeme aj na nádobe z Pincinej (obr. 7). Primárne bola preto používaná v domácom kuchynskom prostredí a len následne využitá pre pohreb diet’at'a.

V predchádzajúcich statiach sme sa mohli stretnút's rôznymi „typmi“ nepokrstených detí. V tomto duchu môžeme podl'a L. Miechowicza $(2007,529)$ rozlíšit' dve kategórie pohrebov tzv. nepokrstených. Prvú predstavujú deti potratené, mŕtvonarodené alebo zomrelé krátko po narodení. Druhú predstavuje nechcené potomstvo, zámerne potratené alebo zabité deti po narodení. Názor o uložení detí v nádobách z dôvodu úkrytu tela diet’at’a po jeho zabití alebo umelo vyvolanom potrate prezentovala vo svojej štúdii E. Kowalczyk (2004, 108-109). Takýmto spôsobom vraj mohli byt' pozostatky detí, ako i placenty matkou alebo tzv. „babou“, ktorá sa venovala potratom, rýchlo a nenápadne vynesené z domu a pochované na tajnom mieste.

Ojedinele sa objavuje názor, že nepokrstené diet’a tým, že sa nestalo krest’anom, bolo prihliadajúc na tradície predkov pochovávané „,starým spôsobom“, čiže v zmysle „,pohanských popolníc“ (Bednárik 1972, 31; porovnaj Kowalczyk 2004, 108).

Pre riešenie otázky dôvodov pochovávania detí v nádobách a ich interpretácie je určite jedným z najdôležitejších menovatel'ov výber miesta. Na Slovensku, kde sú takéto pohreby archeologicky doložené od 14. do 17. storočia, bol výber miesta bezprostredne zviazaný s locus sacer. Hroby sa nachádzali bud' $\mathrm{v}$ tesnom susedstve $\mathrm{s}$ kostolom a jeho cintorínom, avšak už v neposvätenom priestore (Hurbanovo-Bohatá, Krásno), v sutinách zaniknutých kostolov (Gortva-Bizovo, Radol'a, Slovenská L'upča), v priestore zaniknutého kostola a jeho cintorína (Ducové, Pinciná) alebo v neposlednom rade aj priamo v rámci kostolného cintorína (Krásno, Žilina). Podobná situácia je v Nemecku a Mad’arsku - hroby detí sú situované za ohradovým múrom vysväteného priestoru. Iné nálezové prostredie ponúka Pol'sko, kde bolo doposial' zaznamenaných najviac pohrebov detí v nádobách, ktorých výskyt je archeologicky stanovený v rozpätí 13.-19. storočia (Duma 2010, 31-57; 2015, 95-108; Kowalczyk 2004; Miechowicz 2007; Zawadzka-Antosik 1973). Odlišný kontext výskytu hrobov detí znamená, že išlo väčšinou o praveké a protohistorické pohrebiská, ale tiež včasnostredoveké hradisko s menším stredovekým cintorínom, novovekú prícestnú kaplnku a v jednom prípade sutiny domu z obdobia vrcholného stredoveku. Uloženie diet’at’a $\mathrm{v}$ nádobe $\mathrm{v}$ sutinách domu je doposial' jediným známym príkladom (bližšie Duma 2015, 105), preto je ešte predčasné robit' nejaké závery. V prípade pravekých a protohistorických pohrebísk etnografické výskumy dokladajú, že tieto miesta boli obyvatel'mi obce považované za „posvätné“. L. Miechowicz (2007, 528-529) uvádza príklady z Pol’ska, kde sa s konkrétnymi miestami spájajú legendy, že na danom mieste stál kostol, alebo tam bol starý 
cintorín, a pochovávajú sa tu samovrahovia, tragicky zomrelí, mŕtvonarodené deti alebo deti zomrelé bez krstu. Vo väčšine prípadov bola však pre pohreb takéhoto diet’at'a vybraná oblast', ktorá sa nachádza na okraji alebo mimo obce, ,bokom“, avšak v miestach s posvätnou funkciou. Tieto miesta tak boli náhradou za „skutočné cintoríny“ (Miechowicz 2007, 530; Zawadzka-Antosik 1973, 370).

Z uvedeného vyplýva, že nech už okolnosti smrti plodu či novorodenca boli akékol'vek, najbližšia rodina sa mu vo všetkých prípadoch snažila zabezpečit' prítomnost' sacrum alebo bezprostredný kontakt s ním. Vyplývalo to z túžby zaopatrit' zosnulému diet’at'u dôstojný pohreb na posvätnom mieste. Na druhej strane, v niektorých prípadoch doložená „odl'ahlost'“ takýchto miest od obce a spôsob uloženia nádoby (hore dnom, prekrytie inou nádobou alebo kameňom; bližšie v štúdiách Miechowicz 2007; Zawadzka-Antosik 1973) môže vypovedat' aj o možnom strachu z návratu takto zosnulých detí a ich škodlivých aktivít.

Etnologické výskumy dokladajú ešte dlhší časový rámec praktizovania tohto zvyku a jeho existenciu posúvajú až do začiatku 20. storočia. Konkrétne doklady o pochovaní nepokrsteného diet’at’a v hrnčiarskej nádobe sa zaznamenali v historickom regióne Novohrad, do ktorého patrí aj nami pertraktovaná lokalita Pinciná. Zo Starej Haliče pochádzajú svedectvá, že sa takto pochovávali potraty (Bednárik 1972, 29-30). Etnograf Sándor Pintér (1841-1915) uvádza, že v Novohrade sa nepokrstené deti pochovávali v nádobách, ktoré sa ukladali ku kamennému stĺpu. Ten bol situovaný na konci dediny a mal na každej strane výklenok. L’ud ho nazýval kaponka (Malonyay 1922). S. Pintér tiež spomína, že nádoba, v ktorej boli deti v Novohrade pochovávané, sa nazýva širán̆ (Malonyay 1922).V Starej Haliči sa pomenovaním širáň označovala nádoba na kysnutie mlieka (Bednárik 1972, 30). Čo by mohlo naznačovat’ tiež určité symbolické prepojenie túžby poskytnút' diet’at’u „obživu“, ktorá mu bola odopretá náhlym ukončením jeho cesty.

Pomerne bohaté etnografické pramene k pochovávaniu nepokrstených detí sú známe zo susedného regiónu - Gemer. Na Horehroní sa v 17. storočí pochovávali takéto deti na určitom mieste v poli (Bednárik 1972, 30). V Šumiaci pochovávali nepokrstené deti, ako aj samovrahov v kúte cintorína, v Pohorelej vložili nepokrstené diet’a do hrobu príbuzných (Čajánková 1956, 302). Ukazuje sa, že pochovanie nepokrsteného diet'at'a mohlo mat' viacero podôb. Jednou z nich bolo jeho uloženie do hlinenej nádoby.

Z predchádzajúceho je zrejmé, že existuje viacero možností interpretácie nami pojednávanej témy. Či už vo výklade použitia nádoby (praktické či symbolické), vo výbere miesta (rozdiely medzi lokalitami na Slovensku a Pol'sku) alebo v samotnom určení „typu“ zosnulého nepokrsteného diet’at’a. Spoločným menovatel’om všetkých týchto hrobov je však prvotná viera a idea, ktorá stála pri zrode spoločnej tradície. Prikláňame sa k názoru L. Miechowicza $(2007,532)$, že v prípade l’udovej viery a zvykov sa často stretávame so situáciou, že tá istá praktika mohla mat' odlišný výklad v závislosti od regiónu. V tom duchu je potrebné si pripomenút, že za týmito činnostami stojí vždy jeden konkrétny človek, úmysel, idea vynútená konkrétnou situáciou. Za konkrétnym hrobom diet’ata v nádobe sa ukrýva tragédia žitia, túžby a emócie jednotlivca, ktoré len na základe materiálnych zvyškov nie sme schopní jednoznačne vysvetlit' (Miechowicz 2007, 532; Mitáš 2004, 5).

\section{Slovo na záver}

Hrob diet’at’a z Pincinej je možné na základe nálezových okolností (plytké uloženie - hĺbka $0,30 \mathrm{~m}$ ) a nádoby, v ktorej bolo pochované, datovat' pravdepodobne až do 17 . storočia. K pohrebu mohlo dôjst' až v tretej fáze pochovávania na lokalite, teda v období kedy už sakrálna stavba nebola na povrchu takmer rozpoznatel'ná, ale nad’alej sa tu udržiavala tradícia posvätnosti miesta, ktoré bolo prv vysvätené. Keramickú nádobu je možné podl’a tvaru, profilovania okraja a predovšetkým bohatej mal'ovanej výzdoby zaradit' rámcovo do 16.-17. storočia. Ked’že nálezový materiál z hrobov neposkytuje možnost' citlivejšieho datovania, je t’ažké usudzovat', či k pohrebu diet’at’a došlo v rámci novovekej fázy cintorína, avšak vo vymedzenom priestore (okrajová zóna cintorína), alebo sa tak stalo až po ukončení regulárneho pochovávania na lokalite, niekedy v priebehu 17. storočia. 
V článku predstavené nie až tak početné, ale v širšom stredoeurópskom priestore rozšírené hroby detí v keramických nádobách, archeologicky doložené v období stredoveku a novoveku, v 13.-19. storočí, nasvedčujú, že nešlo o ojedinelý a ani izolovaný jav. I ked' sa jednotlivé hroby navzájom mierne líšia $v$ detailoch, ich spoločným menovatel’om je špecifickost' vo výbere lokality, či už v rámci kostolných cintorínov, avšak na vyhradenom mieste (v tesnej blízkosti kostola - pod „odkvapom“" striech, za kostnicou a na vnútornej strane ohrady), za kostolnou ohradou - extra muros, na miestach zaniknutých kostolov a ich cintorínov, v priestore starých pohrebísk - ,posvätná pôda“, v priestore menších cintorínov mimo vysvätenej pôdy, v okolí prícestných kaplniek alebo vel'mi výnimočne v troskách zaniknutých domov. Podl'a antropologických určení deti vkladané do týchto nádob boli identifikované ako plody, novorodenci alebo jedinci vo veku „okolo pôrodu“. V duchu názvu jedného okruhu výstavy Stredoveké Krásno - „Tajomstvo ôsmich nádob", venovanom det’om pochovaných v hrncoch z tejto lokality (Mitáš 2004, 4), môžeme konštatovat', že aj napriek snahe vysvetlit' niektoré javy z minulosti nedokážeme postrehnút' celý rozmer tohto zvyku a jeho celkový obsah. Zostáva len verit', že naše dedukcie a interpretácie sú nasmerované správne. Interpretáciu nálezu z Pincinej ako hrobu nepokrsteného diet’ata dokladajú priamo v regióne etnografické analógie a praktizovanie tohto zvyku posúvajú až do začiatku 20. storočia. To, čo však viedlo matku alebo iného blízkeho príbuzného k uloženiu diet’ata práve do mal'ovaného kuchynského hrnca so stopami používania v Pincinej, zostane už asi navždy nezodpovedané. Nebudeme sa azda mýlit' v presvedčení, že jeho uloženie na mieste s tradíciou posvätného a prv vysväteného priestoru (locus sacer et consecratus) bolo vyjadrením túžby jeho blízkych zabezpečit' mu dôstojné miesto odpočinku, snahy ochránit’ ho pred zlými silami a nádeje, že takéto uloženie mu môže priniest' zlepšenie jeho d’alšieho putovania na onom svete.

Príspevok vznikol v AÚ SAV ako súčast' riešenia projektu VEGA 2/0156/14 „Stredoveké pochovávanie na Nitriansku“a VEGA 2/0091/16 „Slovensko v dobe bronzovej - križovatka súvekých európskych civilizácií“.

\section{Pramene a literatúra}

AO: Anjoukori okmánytár, 1301-1359. Második kötet, 1322-1332 (Nagy, I., ed.). Budapest 1881.

ARIÉS, P., 2000: Dějiny smrti. Praha.

BEDNÁRIK, R., 1972: Cintoríny na Slovensku. Bratislava.

BÉRES, M., 1995: Az óföldeáki erődtemplom. A makói múzeum füzetei 81. Makó.

- 2005: Az Óföldeáki temető üzenete. In: „,...a halál árnyékának völgyében járok“. A középkori templom körüli temetők kutatása. Opuscula Hungarica VI. (Ritoók, A.-Simonyi, E., edd.), 297-303. Budapest.

BLÁHA, J., 1996: Církevní a laická společnost v Olomouci v některých projevech středověké hmotné kultury - Klerikale und laikale Gesellschaft in Olmütz in einigen Äußerungen der mittelalterlichen materiellen Kultur, AH 21, 169-181.

BOROVSZKY, S., 1911: Magyarország vármegyéi és városai. Nógrád vármegye (faksimilné vydanie). Budapest 1988.

BOTOŠ, A., 2012: Novoveká studňa z Rimavskej Soboty - Neuzeitliche Brunnen aus Rimavská Sobota, ZbSNM Archeológia 22, 235-250.

- 2013: Archeologický výskum na ul. B. Bartóka, na mieste bývalej mestskej tržnice v Rimavskej Sobote. In: Gemer-Malohont 8-9. Zborník Gemersko-malohontského múzea v Rimavskej Sobote (Bodorová, O., ed.), 13-28. Rimavská Sobota.

BUDINSKÝ-KRIČKA, V., 1934: Pinciná, okr. Lučenec. Výskumná správa z archeologického výskumu, rkp. ulož. v AÚ SAV v Nitre, č. 2239/34.

ČAJÁNKOVÁ, E., 1956: Pohrebné zvykoslovie Horehronia, Slovenský Národopis 4, 290-305.

ČECHURA, M., 2011: Christian, Non-christian or Pagan: The Burials of newborns as the source to understanding of medieval and postmedieval mentality. In: Kim jesteś człowieku? Funeralia Lednickie. Spotkanie 13 (Dzieduszycki, W.-Wrzesiński, J., edd.), 289-297. Poznań.

DINZELBACHER, P., 2004: Poslední věci člověka. Nebe, peklo, očistec ve středověku. Vyšehrad.

DRĄŻKOWSKA, A., 2007: Powijaki jako podstawowy element garderoby niemowlęcej, Archeologia Gdańska III, 135-141.

DRENKO, Z., 1994: Zaniknutá stredoveká dedina Bizovo, ZbSNM Archeológia 88/4, 129-151. 
DUMA, P., 2010: Grób Alienata. Pochówki dzieci nieochrzczonych, samobójców i skazańców w późnym średniowieczu i dobie wczesnonowożytnej. Kraków.

- 2015: Śmierć nieczysta a Śląsku. Studia nad obrządkiem pogrzebowym społeczeństwa przedindustrialnego - Profane death in Silesia. A study on funeral practices of the preindustrial society. Wrocław.

DZIK, M., 2006: Wczesnośredniowieczne cmentarzysko szkieletowe w Żukowie, pow. Płońsk - Early Medieaval burialground in Żukowo, pow. Płońsk. Warszawa.

FODOR, L.-KOZÁK, K., 1972: Leletegyüttesek a Románkori székesegyház környékéről (Adatok az egri vár XVII-XVIII. századi kerámiájának történetéhez. I.), Az Egri Múzeum Évkönyve VIII-IX/1970-1971, 147-199.

FREIST, W., 1975: Beisetzung einer Frühgeburt in einem mittelalterlichen Tongefäß aus Schöningen, Kr. Helmstedt, Nachrichten aus Niedersachsens Urgeschichte 44, 379-382.

FURMÁNEK, V., 1990: Archeologické pamätníky v Kyjaticiach a Pincinej, ŠZ 26, 369-373.

FURMÁNEK, V.-TÓTHOVÁ, I., 1982: Pinciná, okr. Lučenec. Výskumná správa z archeologického výskumu, rkp. ulož. v AÚ SAV v Nitre, č. 10009/82.

- 1982a: Záchranný výskum v Pincinej. In: AVANS 1981, 83-86. Nitra.

- 1983: Druhá sezóna záchranného výskumu v Pincinej. In: AVANS 1982, 87-88. Nitra.

- 1984: Pinciná, okr. Lučenec. Výskumná správa z archeologického výskumu, rkp. ulož. v AÚ SAV v Nitre, č. $10661 / 84$.

- 1984a: Záverečná sezóna výskumu v Pincinej. In: AVANS 1983, 80-81. Nitra.

GOGOVÁ, S., 2013: Kostolný cintorín v Krásne. Tribečské spoločenstvo vo vrcholnom stredoveku. Hradec Králové.

GYÖRFFY, Gy., 1998: Az Árpád-kori Magyarország történeti földrajza IV. Budapest.

HABOVŠTIAK, A., 1961: Príspevok k poznaniu našej nížinnej dediny v XI.-XIII. storočí - Ein Beitrag zur Erkenntnis unseres Tieflanddorfes im XI.-XIII. Jahrhundert, S1Arch IX, 451-482.

- 1963: Zaniknutá stredoveká dedina Bratka pri Leviciach, SlArch XI, 407-451.

HANULIAK, V., 2001: Zaniknutý kláštor v Slovenskej L’upči, Pamiatky a múzeá, č. 2, 2-8.

HANULIAK, V.-RAGAČ, R., 2000: Príspevok k problematike existencie kláštorného hospica a Kostola sv. Ducha v Slovenskej Lupči, AH 25, 233-244.

HEINTEL, H., 1961: Zwei mittelalterliche Säuglingsbestattungen aus Wernswig, Kr. Fritzlar-Homberg, Fundberichte aus Hessen 1, 127-129.

HOŠŠO, J., 1985: Stredoveké hrnčiarstvo na území Gemera, Novohradu a Hontu, Vlastivedné štúdie Gemera 3, 230-262.

- 2004: Hranica medzi stredovekom a novovekom vo svetle archeologických nálezov keramiky - Die Grenze zwischen dem Mittelalter und der Neuzeit im Lichte der archäologischen Keramikfunde, AH 29, 569-580.

ILLI, M., 1992: Wohin die Toten gingen. Begräbnis und Kirchhof in der vorindustriellen Stadt. Zürich.

JÁGEROVÁ, M., 2008: Posledné zbohom... Súčasné pohrebné obyčaje. Nitra.

KLČO, M.-KRUPA, V., 2004: Stredoveké nálezy z Lančára, okres Piešt’any (kachlice s motívom sv. Martina), Balneologický spravodajca 38/2001-2002, 176-184.

KOVAČEVIČOVÁ, S., 1987: Človek tvorca. Pracovné motívy Slovenska vo vyobrazeniach z 9.-18. storočia. Bratislava.

- 2006: Človek a jeho svet na obrazoch od stredoveku až na prah súčasnosti. Ikonografia Slovenska. Bratislava.

KOWALCZYK, E., 2004: Chrześcijańskie milosierdzie. Rzecz o pochówkach dzieci nie ochrzczonych (na przykladzie pólnocnego Mazowsza). In: Dusza maluczka, a strata ogromna. Funeralia Lednickie. Spotkanie 6 (Dzieduszycki, W.-Wrzesiński, J., edd.), 103-114. Poznań.

KOZÁK, É., 1975: A hollókői vár kutatása, Nógrád megyei múzeumok évkönyve 21, 23-52.

KRÁLIKOVÁ, M., 2007: Pohřební ritus 16.-18. století na území střední Evropy (antropologicko-archeologická studie). Brno.

KRUPICA, O., 1954: Výskum v Krásne na Slovensku v roku 1953, AR VI, 357-359, 361-368.

- 1978: Stredoveké Krásno I, Západné Slovensko 5, 169-333.

KYLL, N., 1972: Tod, Grab, Begräbnisplatz, Totenfeier. Bonn.

LE GOFF, J., 2008: Onen svět. In: Encyklopedie středověku (Le Goff, J.-Schmitt, J.-C., edd.), 454-463. Praha. MALONYAY, D., 1922: A magyar nép müvészete. V. kötet. Budapest. Dostupné z: http://mek.oszk.hu/ 01600/01671/html/index.html?00000.htm \& 00000.htm, cit. 2. 9. 2013, nepaginované.

MIECHOWICZ, L., 2007: Póznośredniowieczne i nowożytne pochówki dzieci w naczyniach glinianych na przykładzie znaleziska z Wyszatyc, gm. Żurawica, pow. Przemyśl - Late Mediaeval and Modern Period Ceramic Vessel Burials of Children: A Case Study of the Find at Wyszatyce (Gmina District of Żurawica, Powiat District of Przemyśl). In: Późne średniowiecze w Karpatach polskich (Garncarski, J., ed.), 517-534. Krosno. 
MITÁŠ, V., 2004: Tajomstvo ôsmich nádob. Deti pochované v hrncoch - nerozlúštená záhada, Historická revue $15 / 4,4-5$.

MORAVČÍK, J., 1996: Kaplnka Božieho tela. Archeologický výskum murovaného objektu pri kostole svätého Štefana. Žilina.

- 2011: Žilina - centrum severného Slovenska: od praveku po stredovek. Žilina.

NAVRÁTILOVÁ, A., 2004: Narození a smrt v české lidové kultuře. Praha.

OHLER, N., 2001: Umírání a smrt ve středověku. Jinočany.

PETROVSKÝ-ŠICHMAN, A., 1963: Výskum zaniknutého stredovekého kostola v Radole, ŠZ 11, 1963, 229-262.

PLOSS, H., H., 1876: Das Kind in Brauch und Sitte der Völker. Anthropologische Studien. I. Band. Stuttgart.

POLÁKOVÁ, Z., 2015: Stredoveké až novoveké kostolné cintoríny z územia dnešného Slovenska s dôrazom k historickým regiónom Gemera, Malohontu a Novohradu. I. čast' - Text, II. čast' - Katalóg, rkp. nepubl. dizertačnej práce ulož. v AÚ SAV v Nitre.

POLLA, B., 1962: Stredoveká zaniknutá osada na Spiši (Zalužany) - Eine untergegangene mittelalterliche Siedlung in der Zips (Zalužany). Bratislava.

RULÍŠEK, H., 2006: Slovník křest’anské ikonografie. Postavy, atributy, symboly. Praha.

RUTTKAY, A., 1984: Ducové „Kostolec“, obec Moravany nad Váhom, okr. Trnava, výskum v rokoch 1968-1972 a 1975. Charakteristika jednotlivých fáz pochovávania. In: Pohřebiště v Ducovém, I. díl (Hanáková, H.-Sekáčová, A.-Stloukal, M., edd.), 5-23. Praha.

- 1992: Novoveká fáza cintorína na „Kostolci“ pri Ducovom (Problematika mincí toliarového obdobia v hroboch), Slovenská numizmatika 12, 91-120.

- 1996: Mittelalterlicher Friedhof in Ducové, Flur Kostolec, Bez. Trnava: Beitrag zum Studium der Beziehungen zwischen den sog. Reihengräberfeldern und Kirchenfriedhofen vor dem 13. Jh. In: Ethnische und kulturelle Verhältnisse an der mittleren Donau vom 6. bis zum 11. Jahrhundert (Bialeková, D.-Zábojník, J., edd.), 391-408. Bratislava.

SEDLÁK, V., 2008: Monumenta Vaticana Slovaciae I. Rationes collectorum pontificiorum in annis 1332-1337. Rím - Trnava.

SLIVKA, M., 1997: Diet’a na prvej i poslednej ceste. Pochovávanie detí v nádobách, Hieron 2, 71-85.

- 2004: Hranice v mentálnom chápaní stredovekého človeka - Grenze in der Mentalwahrnehmung des mittelalterlichen Menschen, AH 29, 9-36.

ŠTAJNOCHR, V., 2001: Funerální nádoby - smrt a život post mortem v mytické skutečnosti. In: Fenomén smrti v české kultuře 19. století (Lorenzová, H.-Petrasová, T., edd.), 334-348. Praha.

TONER, P., J., 1910: Limbo. In: The Catholic Encyclopedia, vol. 9, 256-259. New York.

TÓTHOVÁ, I., 1988: Archeologický výskum v Pincinej. Sprievodca k výstave. Lučenec.

TROCHTA, J., 1971-1972: Zoznam stredovekých fár na Slovensku, zostavený podla účtovných registrov pápežských kolektorov o desiatkových poplatkoch zaplatených užívatel'mi cirkevných benefícií v Uhorsku v rokoch 1332-1337 pre pápežskú kúriu v Avignoni, VIII. Novohradská stolica, rkp. ulož. v Historickom ústave SAV v Bratislave.

UNGER, J., 2006: Pohřební ritus 1. až 20. století v Evropě z antropologicko-archeologické perspektivy. Brno.

V. B. [V. Budaváry], 1939: Prehl'ad prírastkov archeologického oddelenia Slovenského národného muzea v T. Sv. Martine, nadobudnutých v r. 1931-1933, Časopis Muzeálnej slovenskej spoločnosti 30/1-4, 11-16.

VASS, É., 1993: A szécsényi szandzsák 1554. évi adóösszeírása, A Nógrád Megyei Múzeumok Évkönyve 18/1992-1993, 9-102.

ZAWADZKA-ANTOSIK, B., 1968: Badania na grodzisku wczesnośredniowiecznym w miejscowośći Serock, pow. Nowy dwór Mazowiecki, Wiadomości Archeologiczne 33/3-4, 362-367.

- 1973: Pochówki dzieci w naczyniach glinianych, Wiadomości Archeologiczne 38/2, 365-371.

\section{Zusammenfassung}

\section{Ein Kindergrab in einem Gefäß aus der Fläche einer untergegangenen Kirche und eines nicht mehr genutzten Friedhofs in Pinciná (Bezirk Lučenec)}

In den Jahren 1981-1984 wurde in der Gemeinde Pinciná (mittlere Eipel-Region, südliche Mittelslowakei) in der Lage Temetődomb (Abb. 1-3) eine systematische archäologische Rettungsgrabung durchgeführt, bei welcher der Grundriss einer spätromanischen Kirche erfasst und der in den Zeitraum zwischen der Wende des 12. und 13. Jahrhunderts bis zum 17. Jahr- 
hundert datierte Kirchenfriedhof untersucht wurde. (Abb. 4; Furmánek-Tóthová 1982; 1982a; 1983; 1984; 1984a). Durchgeführt wurde die Grabung vom Archäologischen Institut der Slowakischen Akademie der Wissenschaften in Nitra (V. Furmánek) in Zusammenarbeit mit dem Novohrad-Museum in Lučenec (I. Kaczarová, geb. Tóthová). An der Fundstelle konnten drei Bestattungsphasen untergliedert werden, wobei die zweite und dritte Phase mit dem Ende der sakralen Funktion der Kirche verbunden ist (Abb. 5, 6), zu der es spätestens in der zweiten Hälfte des 16. Jahrhunderts gekommen war. Zwischen der Zeit, als der Bau unterging und seinem definitiven Verschwinden ist bestimmt ein längerer Zeitabschnitt vergangen, was auch die sehr unterschiedliche Orientierung der Gräber der in der dritten Phase bestatteten Personen bedingte, als die Kirche an der Oberfläche bereits fast nicht mehr erkennbar gewesen sein konnte und man lediglich die Bestattungstradition in diesem Bereich (locus sacer et consecratus) beibehalten hatte. Bei der Revision des Fundbestandes wurden in den Depots des Novohrad-Museums und Galerie in Lučenec Scherben aus einem rekonstruierbaren Gefäß identifiziert, das auch den ursprünglichem Inhalt enthielt, und zwar von Kindern stammende Gebeine (Abb. 7-9). Gerade dieses aus einem Gefäß bestehende Kindergrab ist Gegenstand des vorliegenden Beitrags. Im Jahr 1982 wurde das Gefäß aus einer Tiefe von 0,30 m aus Sondierschnitt III-A-2 gehoben, der im Außenbereich der südwestlichen Ecke des Kirchenschiffs lag und teilweise auch in den Raum von dessen zerlegtem Mauerwerk hineinreichte. Das auf einer Töpferscheibe gedrehte Gefäß (H $220 \mathrm{~mm}$, der Mündung $150 \mathrm{~mm}$ und $\varnothing$ des Bodens $100 \mathrm{~mm}$ ) hat eine topfartige Form, einen seitlichen Bandhenkel und ist reichverziert mit einem rotbraunen gemalten Dekor. Es weist Gebrauchsspuren auf. Anhand seiner Form, Randprofilierung und vor allem wegen der reichen gemalten Verzierung kann es grob dem 16.-17. Jahrhundert zugeordnet werden (Botoš 2012; 2013; Fodor-Kozák 1972; Hoššo 1985; Kozák 1975). Durch die Fundumstände (vor allem durch die sehr flache Tiefe von 0,30 m) können wir annehmen, dass es erst in der dritten Bestattungsphase zum Begräbnis des Kindes in dem Gefäß gekommen war. Die Fundsituation ermöglicht es jedoch nicht zu beurteilen, ob dies im Rahmen der neuzeitlichen Phase des Friedhofs, desungeachtet jedoch in deren umgrenztem Bereich (in deren Randzone), oder erst nachdem die regulären Bestattungen an der Fundstelle eingestellt worden waren, irgendwann im Laufe des 17. Jahrhunderts erfolgt war.

Für die Klärung der Frage, warum Kinder in Gefäßen bestattet wurden und deren Interpretation, ist die Wahl des Ortes sicherlich einer der wichtigsten Nenner. In der Slowakei, wo solche Bestattungen von der historischen Archäologie für die Zeit vom 14. bis zum 17. Jahrhundert belegt sind, war die Wahl des Ortes unmittelbar mit einem Locus sacer verbunden. Die Gräber befanden sich entweder in dichter Nachbarschaft zu einer Kirche und ihrem Friedhof, allerdings im nicht geheiligten Raum extra muros (Hurbanovo-Bohatá, Krásno), oder im Schutt von untergegangenen Kirchen (Abb. 10; Gortva-Bizovo, Radol'a, Slovenská L’upča), im Raum einer untergegangenen Kirche und ihres Friedhofs (Ducové, Pinciná), oder nicht zuletzt auch direkt im Rahmen eines Kirchenfriedhofs (Krásno, Žilina). Eine ähnliche Situation liegt in Deutschland und Ungarn vor. Eine andere Fundumgebung bietet Polen. Gefäße mit den Gebeinen von Kindern befanden sich meist im Bereich von urzeitlichen und protohistorischen Gräberfeldern, aber auch auf frühmittelalterlichen Burgwällen mit einem kleineren mittelalterlichen Friedhof, bei neuzeitlichen an Wegen gelegenen Kapellen und im Schutt eines Fachwerkhauses aus der Zeit des Hochmittelalters. Ihr Vorkommen ist für die Zeitspanne zwischen dem 13.-19. Jahrhundert belegt (Duma 2010, 31-57; 2015, 95-108; Kowalczyk 2004; Miechowicz 2007; Zawadzka-Antosik 1973). Im Rahmen von Mitteleuropa war die nächste Familie jedoch in allen Fällen darum bemüht, für das verstorbene Kind die Anwesenheit eines Sacrum oder einen unmittelbaren Kontakt dazu zu gewährleisten. Dies basierte auf der Sehnsucht, dem entschlafenen Kind ein würdiges Begräbnis an einem heiligen Ort zu verschaffen. Andererseits ist in einigen Fällen auch eine Lage abseits des Dorfes belegt, was zusammen mit der Art der Niederlegung des Gefäßes (näheres in den Studien Miechowicz 2007; Zawadzka-Antosik 1973) auch eine mögliche Angst vor der Rückkehr dieser Kinder und ihren schädlichen Aktivitäten andeuten kann. 
Die Interpretation des Fundes aus Pinciná als Grab eines ungetauften Kindes (Abb. 11-13) wird gerade in der historischen Region Novohrad, zu welcher die Fundstelle zählt, durch ethnographische Analogien belegt und verlegen die Praktizierung dieses Brauchs bis an den Anfang des 20. Jahrhunderts. Aus dem Alten Galizien stammen Zeugnisse, dass Fehlgeburten auf diese Weise bestattet wurden (Bednárik 1972, 29-30). Der Ethnograph Sándor Pintér (1841-1915) gibt an, dass ungetaufte Kinder in Novohrad in Gefäße gelegt wurden, die man dann an einer Steinsäule begrub, welche sich am Ende des Dorfes befand und Kaponka genannt wurde (Malonyay 1922).

Trotz der historischen und ethnographischen Quellen, welche den Fund aus Pinciná in einen Kontext setzen können, wird es wohl nie möglich sein, eine Antwort auf die Frage zu finden, was eine Mutter oder einen anderen nahestehenden Verwandten dazu bewegt hatte, ein Kind gerade in einen bemalten Topf mit Gebrauchsspuren zu legen. Wir werden uns wohl nicht in der Überzeugung irren, dass seine Niederlegung an einem traditionellen heiligen und zuvor geweihten Ort (locus sacer et consecratus) Ausdruck der Sehnsucht seiner Nächsten war, ihm einen würdigen Ort der Ruhe zu gewährleisten und vom Bestreben geleitet wurde, es vor bösen Kräften zu schützen sowie die Hoffnung in sich barg, dass eine solche Niederlegung eine Verbesserung seiner weiteren Pilgerschaft im Jenseits bedeutete.

Der vorliegende Beitrag entstand im Archäologischen Institut der Slowakischen Akademie der Wissenschaften als Teil des Projektes VEGA 2/0156/14 „Mittelalterliche Bestattungen in der Region Neutra“ und VEGA 2/0091/16 „Die Slowakei in der Bronzezeit - Kreuzungen zeitgenössischer europäischer Zivilisationen“.

Mgr. Zuzana Poláková, PhD, Archeologický ústav SAV, Akademická 2, SK 94921 Nitra,

Slovenská republika,nrauzpol@savba.sk

Dr. h. c. prof. PhDr. Václav Furmánek, DrSc., Archeologický ústav SAV, Akademická 2, SK 94921 Nitra, Slovenská republika,nraufurm@savba.sk

PhDr. Iveta Kaczarová, Novohradské múzeum a galéria, Kubínyiho námestie 3, SK 98401 Lučenec, Slovenská republika,nmlc@stonline.sk 
